\title{
El palacio de los Torres de Portugal en Villardompardo (Jaén). Análisis de una residencia nobiliaria del siglo $\mathrm{XVI}$
}

\author{
The palace of the family Torres de Portugal in Villardompardo (Jaén). Proposal \\ for the reconstruction of a nobiliary residence of the XVI century.
}

Vicente Salvatierra Cuenca ${ }^{1}$; Mercedes Navarro Pérez²; Irene Montilla Torres ${ }^{3}$

Recibido: $12 / 06 / 21$

Aceptado: 01/07/21

Publicado: 03/09/21

\begin{abstract}
RESUMEN
Se propone la reconstrucción del palacio de los condes de Villardompardo, en la localidad del mismo nombre. Este fue resultado de la transformación realizada en el siglo XVI de un pequeño castillo. Se parte de las evidencias arqueológicas, relacionándolas con la descripción contenida en el catastro del marqués de la Ensenada y de otra documentación escrita disponible. De esta forma se recupera la planta y la distribución de los edificios fundamentales del palacio. A partir de lo cual se analiza el conjunto desde un punto de vista funcional y social. Y se discute si, pese a su tamaño y localización, puede relacionarse con alguna de las concepciones de los grupos de la alta nobleza de la época, que articularon las relaciones entre palacios y poblaciones.
\end{abstract}

Palabras clave: Palacio; arqueología de la arquitectura; reconstrucción; siglo XVI; funcionalidad; sociedad

\section{INTRODUCCIÓN}

El análisis de los grupos sociales en época moderna, que ha tratado de profundizar en el estudio histórico de la vida cotidiana, se ha desarrollado considerablemente en las últimas décadas. Ello implica, también, valorar cada uno de esos grupos desde la perspectiva de la cultura material, en la que se incluye de forma particular la vivienda. Por lo que se refiere a la nobleza, uno de los fenómenos más visibles, entre los siglos XV y XVI, fue el abandono o la transformación de los castillos como lugar de residencia.

\begin{abstract}
In this article, the palace of the Counts of Villardompardo, in the town of the same name, is analysed. This palace was the result of the transformation of a small castle carried away in the $16^{\text {th }}$ century. We will start from the archaeological evidence, relating it to the description contained in the Catastre of the marqués de la Ensenada and other available written documentation. In this way, the plan and the distribution of the fundamental buildings of the palace are recovered. From this point, the ensemble is described from a functional and social point of view. And it is discussed, if despite its size and location, it could be related to any of the conceptions of the groups of the high nobility of the time, which articulated the relationships between the palaces and villages.
\end{abstract}

Keywords: Palace; archeology of architecture; reconstruction; $16^{\text {th }}$ century; functionality; society

En las dos últimas décadas, el Laboratorio de Arqueología de la Arquitectura de la Universidad de Jaén, ha llevado a cabo estudios en diversos palacios de la provincia, algunos de ellos originados en castillos, y en su mayoría con una clara impronta renacentista (MONTILLA, NAVARRO, 2014). Recientemente se ha iniciado un programa de reevaluación de esos edificios, con el objetivo de explicar sus transformaciones y estudiar la funcionalidad y el uso social de los mismos en cada momento. Como se ha expresado en diversas ocasiones "la casa es más que los muros que la definen o que la arquitectura que la sustenta" (GARCíA

1. Universidad de Jaén.vsalvati@ujaen.es, http://orcid.org/0000-0003-0467-6537

2. Universidad de Jaén. mnperez@ujaen.es, http://orcid.org/0000-0001-6440-6737

3. Universidad de Jaén. irene.montilla@ujaen.es, http://orcid.org/000-0003-2559-4821

Cómo citar: Salvatierra Cuenca, V., Navarro Pérez, M., Montilla Torres, I. (2021): El palacio de los Torres de Portugal en Villardompardo (Jaén). Análisis de una residencia nobiliaria del siglo XVI. Arqueología y Territorio Medieval, 28. e6422. https://doi.org/10.17561/aytm. v28.6422 
CONZÁLEZ, 2017: 46). Pero sin conocer esta, es muy difícil comprender cómo se utilizaba.

El presente trabajo, centrado en el castillo de Villardompardo, forma parte de este proyecto. Se trata de un castillo edificado en la segunda mitad del siglo XIII por la ciudad de Jaén, dentro de su territorio, y situado frente a las tierras de la Orden Militar de Calatrava (fig. 1), que fue transformado en un palacio en la segunda mitad del siglo XVI. Este último fue destruido excepto los muros perimetrales y una torre entre los siglos XIX y XX, convertido en plaza de toros durante un breve periodo, y luego abandonado (fig. 2).

\subsection{Villardompardo y su castillo}

La población de Villardompardo se encuentra a 20,10 kilómetros al noroeste de Jaén (a $31,6 \mathrm{~km}$ por carretera), en una loma a $480 \mathrm{~m}$ de altura sobre el nivel del mar, en el pie de monte del Frente Externo de las Cordilleras Béticas. Su ubicación en el margen izquierdo del arroyo Salado de Los Villares le garantiza

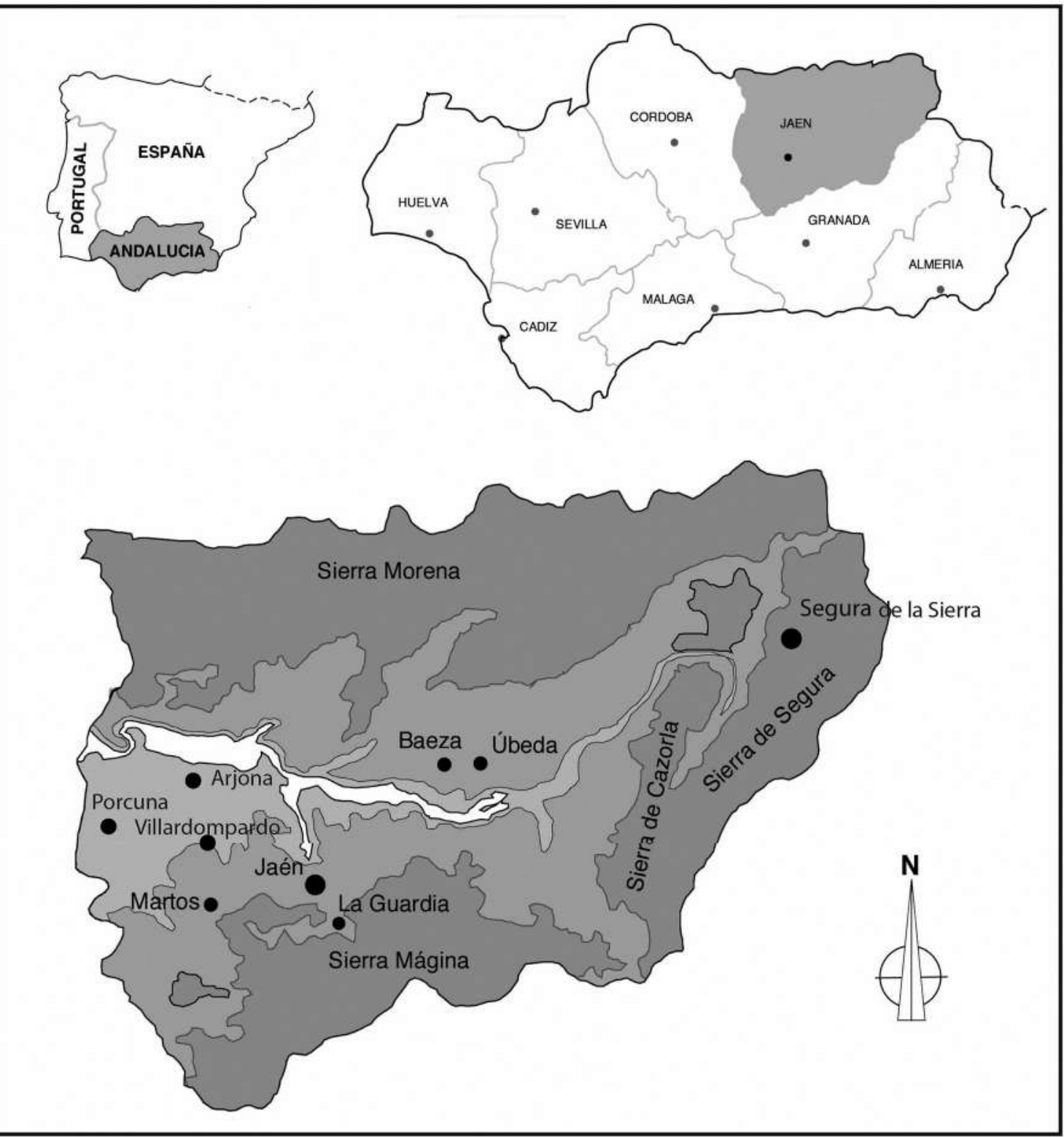

Fig. 1 Plano general. Situación de la localidad de Villardompardo 


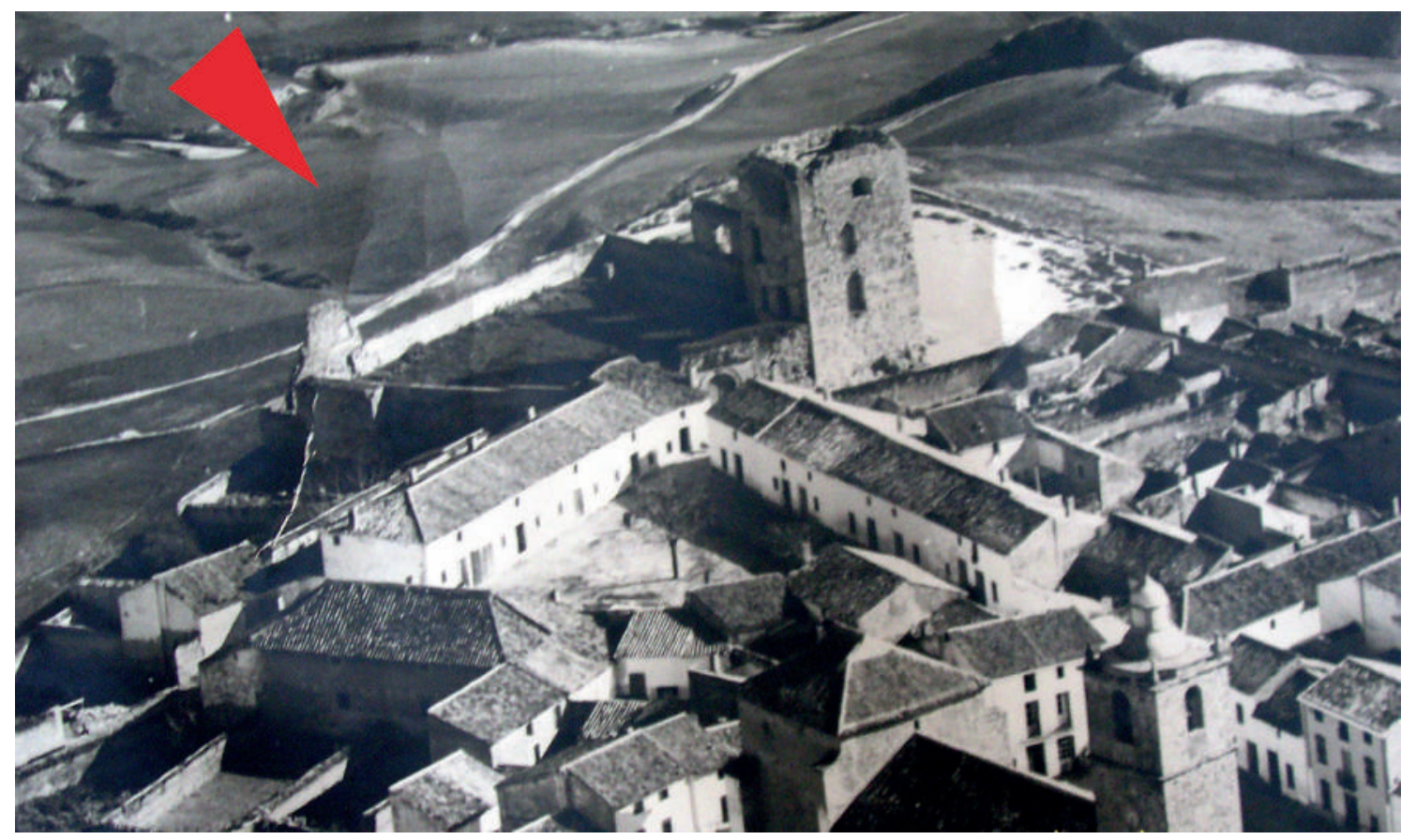

Fig. 2 El recinto del castillo-palacio a finales del siglo XX. Panorámica desde el oeste

abundante agua y fértiles vegas en su entorno más próximo ${ }^{4}$. El castillo-palacio se encuentra situado en el extremo este, al pie de la colina en la que se alza la población.

Se trataba de una pequeña fortaleza, semejante a muchas otras de las que existieron en la campiña tras la conquista cristiana, sedes de las alcaidías de las aldeas pertenecientes al concejo, compuestas por una torre dentro de un recinto. En este caso conforma un polígono irregular, protegido por una acusada pendiente en su lado este, límite de la colina en la que se asienta. La torre ocupaba el ángulo suroeste, a la que se adosaban los muros oeste y sur. En la segunda mitad del siglo XVI, antes de que sus propietarios obtuviesen el título de condes, realizaron numerosas transformaciones, convirtiendo el antiguo castillo en una residencia con mayores comodidades, que llegó a considerarse un palacio. Los cambios se advierten aún en la portada, en la torre y en los datos que se han documentado sobre los edificios hoy desaparecidos. Este recinto no fue recogido por Ximena Jurado en el siglo XVII, que sí dibujó la mayoría de las fortificaciones del entorno, incluida la torre de la vecina Escañuela, posiblemente porque tanto esta como las murallas estaban enmascaradas por las construcciones modernas del palacio, lo que impedía ver la clara función defensiva primigenia del lugar. La descripción más antigua con la que contamos es la contenida en el catastro del marqués de la Ensenada, en 1751.

\subsection{Metodología}

En este texto se resumen los datos sobre los sucesivos propietarios, los relativos a las estructuras que formaron parte del palacio, y se propone una reconstrucción de este último. Para esto hemos partido del estudio de las estructuras arqueológicas, de las que se realiza un análisis minucioso. Cuando hablamos de arqueología casi siempre se viene a la imaginación la idea de un estudio sobre el territorio ${ }^{5}$, o de actuaciones relacionadas con

\footnotetext{
4. Se localiza en la Hoja 925 Porcuna 925-4 Villardompardo, del plano MTN50, a escala 1:50.000 del Instituto Geográfico Nacional, edición de 2007. Y en la hoja 3-4/925/12-20 del plano a escala 1:2.000 de la Consejería de Obras Públicas, de la Junta de Andalucía, de 1988 .

5. Este campo de la arqueología también ha sido utilizado en este estudio. A él nos referimos sucintamente en la parte final del trabajo.
} 
la excavación; en este sentido, el solar del antiguo castillo-palacio y su entorno inmediato (vivienda adosada al norte, plaza al sur y parte superior de la ladera este), fueron excavados entre 2012 y 2020, recuperando numerosas estructuras y material mueble.

Pero la arqueología actual tiene un tercer campo metodológico, la arqueología de la arquitectura, que es una estrategia imprescindible para abordar el estudio de los edificios históricos. Además de permitir conocer mejor la historia de una construcción, este método es un complemento del proyecto de consolidación y restauración que, si utiliza sus resultados, permite racionalizar y sistematizar el propio proyecto, ayudando en la toma de decisiones acerca del mismo, potenciado unas fases históricas sobre otras y, dependiendo de la conservación o de otros elementos como la puesta en valor del edificio, obteniendo una mejor comprensión de este. Además, "la arqueología de la arquitectura posibilita también una visión radicalmente nueva de la historia de la arquitectura, desligada de la historia de los estilos y donde cada edificio no es representación de un modelo de estudio, sino resultado único y personal de una experiencia" (AZKÁRATE, CABALLERO, QUIRÓS, 2002: 8).

Este método se basa en el estudio de los paramentos, cuyo primer paso es la realización de la topografía y la fotogrametría de los mismos (CÁMARA, LATORRE, 2003; MILETO, VEGAS, 2003). Sobre esta base gráfica se identifican las unidades estratigráficas (UUEE), cada una de las cuales se refiere a uno de los aparejos que es posible distinguir en cada paramento, o a las actuaciones sobre el mismo y que se entienden en este contexto como un momento de construcción, reforma, abandono o destrucción. Por tanto, cada acción queda reflejada en una o varias UUEE. El examen de la relación entre los aparejos, que incluye las evidencias de que han sido transformados, permite reconstruir la secuencia cronológica en la que se construyeron, para lo que se emplean también los enfoscados y enlucidos, que pueden cubrir a unos aparejos y ser cortados al introducir otros. Ello permite identificar las modificaciones sufridas por los edificios, desde reformas en profundidad (levantamiento de nuevas plantas), hasta la apertura o cierre de vanos, y la realización de un análisis sincrónico y diacrónico, que permite establecer la secuencia cronológica y constructiva del edificio (MONTILLA, NAVARRO, 2011). Junto a las imágenes relativas a la lectura de los lienzos más significativos, se incluye la relación de UUEE, indicando las acciones que representan y la Matrix Harris, donde las relaciones estratigráficas de anterioridad y posterioridad se representan verticalmente, y las sincrónicas a nivel horizontal (HARRIS, 1991).

Las excavaciones en el castillo Villardompardo han mostrado que este se organiza en amplias zonas que conforman una planta baja al oeste, norte y este, que quedaron enterradas cuando el recinto se acondicionó como plaza de toros. Pero solo en los paramentos perimetrales es posible analizar la existencia de uno o más pisos. Se han realizado procesos de documentación fotogramétricos a lo largo de los varios años que duraron los trabajos arqueológicos, de forma que se dispone de una documentación muy completa y homogénea ${ }^{6}$. Sobre las sucesivas secuencias obtenidas se efectuaron estudios detallados, obteniéndose un listado completo de las transformaciones observables. Lamentablemente las alteraciones y transformaciones sufridas por los distintos paramentos han dificultado la obtención de una secuencia completa en todos los ámbitos. Hay diferencias importantes en la torre del homenaje, donde las caras este y norte han conservado huellas y evidencias de buena parte de las transformaciones que sufrieron, mientras que las caras sur y oeste fueron transformadas y regularizadas profundamente durante un proceso de restauración llevado a cabo en 1987, por las malas condiciones en las que se encontraban, aspecto que también afectó a la cara exterior de todo el paramento sur. Por su parte el recinto amurallado presenta diferencias en cada uno de sus lados. El muro oeste fue

6. El trabajo fue efectuado por la empresa Toposur. Proyectos y Topografía S. L. 
despojado, tanto al exterior como al interior, del material que debía de formar sus camisas, siendo imposible determinar los espacios en los que pudo estar dividido. Por su parte la muralla norte también fue modificada; fue rebajada en forma de escalones para acondicionarla como grada para convertirla en el límite de la plaza de toros, mientras que la situada frente a ella, que limitaba con el borde sur del camino de acceso a la plaza de armas, fue rebajada hasta poco más de 1,60 m de altura, enrasándose con aquella. Es la misma situación en la que se encuentra el largo muro este. Solo el muro sur conserva su altura y el revestimiento interior, aunque el exterior fue regularizado y uniformizado en 1987. En definitiva, el análisis que ha podido realizarse de los paramentos es muy parcial.

Estas deficiencias se han tratado de compensar en parte con otros elementos, empleando el conjunto para correlacionar las estructuras arqueológicas principales con los distintos cuerpos que se recogen en la descripción del catastro del marqués de la Ensenada (ENSENADA, 1751). El análisis arqueológico y la descripción citada constituyen el entramado de la reconstrucción que se propone. A partir de ellos se ha tratado de recuperar la imagen que debía de tener el edificio mediante una serie de correlaciones e interpretaciones, plasmadas en dibujos y proyecciones, inevitablemente hipotéticos.

Junto a ello se han integrado en el estudio las noticias disponibles sobre los condes, así como los datos proporcionados por diversos documentos, incluidos en estudios que se han ocupado de temas en apariencia muy alejados de nuestro objeto, que van desde la organización eclesiástica bajomedieval a la rejería jienense, o al análisis artístico-tipológico de estructuras como la portada, todo lo cual se cita en el lugar correspondiente. El estudio se completa con el planteamiento de algunas propuestas sobre la funcionalidad material y social de cada uno de los espacios, y la relación del conjunto con las tendencias impulsadas por algunos grupos de la alta nobleza en la época.

\section{LOS CONTEXTOS}

Son múltiples los elementos que inciden en los procesos de renovación social, urbana y arquitectónica que se producen a partir del siglo XIV. No resulta posible, por razones de espacio, referirnos a todos ellos, por lo que solo aludiremos brevemente a los que afectan más directamente a nuestro objeto de estudio.

\subsection{Las élites y sus residencias entre los siglos XV y XVI}

En Castilla, desde mediados del siglo XIV, empiezan a abandonarse los castillos y las grandes torres como lugar de residencia, y se inicia la construcción de nuevos edificios. Aunque la tendencia está representada por algunos reyes como Alfonso XI o Pedro I, muy influidos por los palacios andalusíes, la transformación responde a las nuevas necesidades de la organización de la 'casa' de la nobleza. Esta, consolidada a lo largo de siglo XV, si bien siguió construyéndose durante el Antiguo Régimen, estaba concebida para cubrir distintas funciones y dar cabida a un numeroso grupo de personas de distinta condición, por lo que debía responder a varios criterios. Era, en buena medida, un lugar de representación pública, lo que exigía que existieran determinadas salas destinadas a ese fin. Pero, teniendo en cuenta los criterios jerárquicos, también debía haber otras estancias menores donde el señor pudiera recibir a sus visitantes según el nivel social de los mismos. Existía una rigurosa separación por sexos, con las habitaciones privadas del señor vinculadas a las salas anteriormente citadas, mientras que las de la señora estarían en un lugar distinto, 'protegido' de las miradas de los extraños (BLASCO, 2006: 50-59; 2017: 68-70). Por otro lado, si se pretendía que la residencia pudiera estar habitada durante temporadas más o menos largas, debía tenerse en cuenta el número de miembros de la «familia» que en un momento dado podía vivir en la misma. Durante el Antiguo Régimen este término "tenía el significado del grupo doméstico que incluye a los 
sirvientes (pero que excluye a los familiares no residentes) y que enlaza con la idea del patrimonio" (CASEY, 1991: 154). En estos edificios se integrarán las tendencias artísticas que conviven y evolucionan en la época, incorporando paulatinamente los nuevos conceptos renacentistas.

En los últimos años se han estudiado algunos de estos castillos-palacios, pertenecientes, en general, a los niveles más altos de la nobleza, construidos en las principales ciudades o en las que constituían el centro de los 'estados' de esos aristócratas, ciudades que se habrían configurado como proyectos ideológicos destinados a fijar una imagen distintiva de esas élites. En este sentido se ha señalado la existencia entre parte de la alta nobleza castellana de los siglos XV y XVI, con grandes propiedades sobre todo en el centro y sur peninsular, de dos grandes 'facciones', encabezadas respectivamente por los Mendoza y los Álvarez de Toledo, duques de Alba. Los primeros personificarían el sector que propició el desarrollo económico y demográfico a través del comercio, y que se identificó con la cultura humanística del renacimiento, impulsando un proceso de renovación urbana, arquitectónica y artística, en la que los 'palacios' situados en esas localidades se integrarán en la población al dotarlos de una fachada que preside una amplia plaza y supone al mismo tiempo una auténtica escenografía. Frente a ellos, los duques de Alba habrían optado por seguir apoyándose en la economía rentista, y las tradiciones caballerescas, simbolizadas en la apariencia del castillo amurallado que dominaba la localidad, aunque profundamente reformado interiormente, y que se mantiene apartado de la población (ALEGRE, 1999: 849-855; 2008: 2-4; ARANDA, 2019:9-11).

Aunque este modelo ha sido concebido a partir del análisis de las villas ducales, es posible que nobles con menor poder y medios trataran de integrar en sus propios señoríos algunos elementos de uno u otro modelo, mostrando de esta forma su adhesión a la 'facción' correspondiente.

\subsection{El lugar y los señores de Villardompardo}

La localidad fue fundada hacia 1245 , durante la conquista del Alto Guadalquivir por Fernando III, a unos $20 \mathrm{~km}$. de la ciudad de Jaén, aunque es difícil saber cuándo comenzaría la construcción de la misma. Algún tiempo después de la ocupación de Jaén, quedaría como aldea de su concejo (ESLAVA, 1999: 193-195). El caserío se situó en la cima de una pequeña loma, cuyo lado este bajaba suavemente a lo largo de unos 70 u 80 m, existiendo después un fuerte cortado hasta el valle del arroyo Salado de los Villares. En ese borde, donde existían restos de un complejo asentamiento romano, el concejo levantó un pequeño castillo (fig. 3) a finales del siglo XIII (MONTILLA, NAVARRO, SALVATIERRA, 2021), para defender los intereses de la ciudad frente a la Orden de Calatrava, que controlaba el territorio situado al este del distrito jienense, con las poblaciones de Torredojimeno, Porcuna, Martos y otras.

En el último cuarto del siglo XIV, Enrique II favoreció a los linajes que le habían apoyado frente a su hermanastro Pedro I. En Jaén el principal de estos era Pedro Ruiz de Torres, a quién le concedió los derechos de la almocatracía, el estanco sobre el tinte y otros (PORRAS, 1989: 64-67; ALCÁZAR, 2008: 162-164). A principios del siglo XV probablemente Juan II (1406-1454) entregó en señorío la aldea y el término de Villardompardo a Fernando de Torres, heredero del mayorazgo. De esta forma, los Torres (Tabla 1) se convirtieron en uno de los linajes más poderosos de la ciudad, a la que tratarían de controlar en abierta disputa con la rama local de los Mendoza, que a su vez habían sido relativamente engrandecidos por Juan I y Enrique III (PORRAS, 1990: 273-280).

En la segunda mitad de dicho siglo será señora de Villardompardo Teresa de Torres (1442-1521). Enrique IV la casó en 1458 con el Condestable de Castilla, Miguel Lucas de Iranzo. Tras su asesinato en 1473, marginados los Mendoza de Jaén por su participación en el mismo, y muerto Enrique IV al año siguiente, Teresa de Torres y su hijo Luis (1468-1510) 

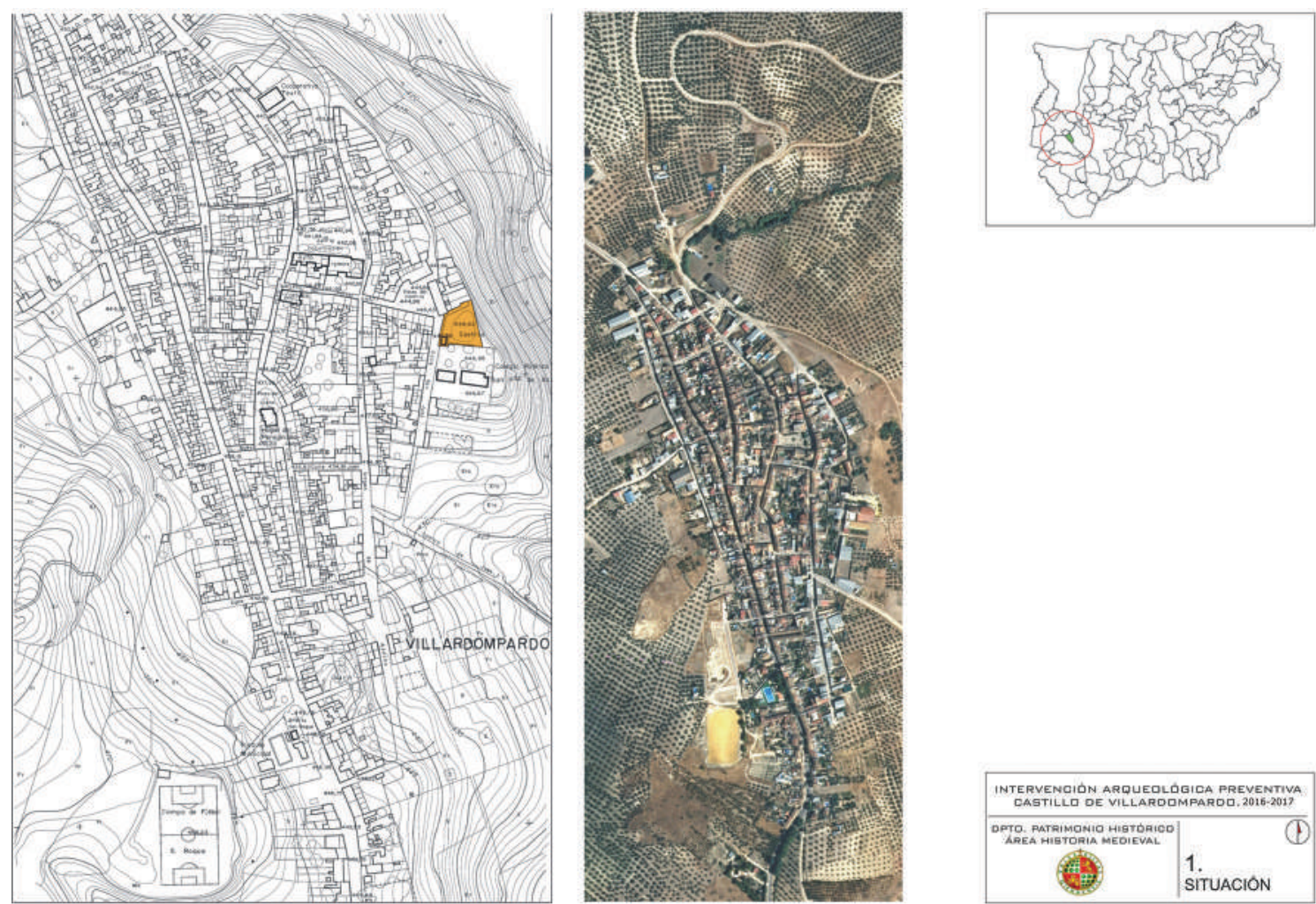

Fig. 3 La localidad de Villardompardo y la situación del castillo-palacio en la actualidad

\section{Tabla 1. Genealogía de los Torres y los Torres y Portugal (siglos XV y XVI)}

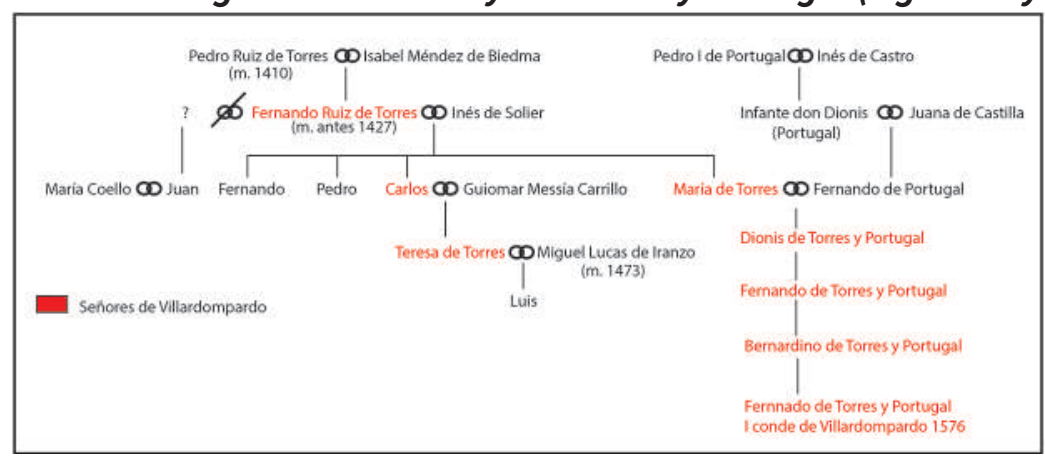

consiguieron el apoyo de Isabel I y recibieron casi todos los cargos que había tenido el Condestable. Pero en 1499, Luis tomó los hábitos. Y al año siguiente su madre profesó como monja clarisa (PEREA, 1981: 229-235; PORRAS, 1990: 282; CUEVAS, ARCO, ARCO, 2001: XIII-XIV; L-LI.).

Estas iniciativas religiosas no resultan sorprendentes si las comparamos con la actuación de otros muchos nobles. Ello se ha puesto en relación con la penetración de las propuestas espirituales de las órdenes mendicantes en el entorno cortesano, cuando se forjó una alianza, en la que las primeras obtuvieron el apoyo de los segundos, al tiempo que la nueva espiritualidad se integraba en las estrategias políticas y sociales de poder de la nobleza. Pero, además, esa espiritualidad convirtió "el entorno cortesano en una colmena de beatas, religiosas, frailes y 'hombres devotos'” (PÉREZ, 2011: 138). 


\subsection{La reorganización de las elites. Los Torres: guerreros, funcionarios, rentistas}

La falta de herederos directos hizo pasar el señorío de Villardompardo a una rama lateral de la familia, los descendientes de María de Torres y de Fernando de Portugal (NICÁS 1997: 427-428). Este era nieto de Pedro I de Portugal, e hijo del infante Don Dionis y de Juana de Castilla, hija de Enrique II. El heredero, Fernando de Portugal y Torres cambió el orden de sus apellidos al recibir el señorío. Adquiría con este una sólida posición económica, pero no obtuvo el poder político que los Torres habían ostentado en la ciudad, ya que no recibió los cargos que habían tenido aquellos. Aparentemente, los reyes aprovecharon el final de la línea sucesoria principal para romper sus acuerdos con Teresa de Torres, y situar en la ciudad a alguien más próximo a ellos, en concreto a Antonio de Fonseca, señor de Coca y Alaejos que, junto al obispo Alonso Suárez de la Fuente del Sauce, configurarían el nuevo poder político en la ciudad, en detrimento de las antiguas familias. Frente a ellos se posicionaron los Messía, señores de La Guardia y Santa Eufemia, iniciando un nuevo ciclo de enfrentamientos ciudadanos (RAMOS, 2002: 100).

No hay datos sobre la actuación en la ciudad, o en el señorío, de D. Fernando de Torres y Portugal, que debió de morir hacia 1509-10. El sucesor de este, Bernardino, después de alguna peripecia ${ }^{7}$, se casó con María Messía-Carrillo Ponce de León, aliándose así con Rodrigo Messía, el único que podía ayudarle a recuperar el poder que había tenido su familia. Fruto de este matrimonio nacería Fernando de Torres, el futuro I conde de Villardompardo. En 1520 Rodrigo Messía y Bernardino de Torres estarán entre los cabecillas de la insurrección de las Comunidades de Castilla en Jaén. Su rebelión duró muy poco y en marzo de 1521 se habían sometido. Fueron perdonados, pero Bernardino murió al año siguiente (PORRAS, 1993: 14 y 68).
El rey pudo perdonar, pero no olvidar. En abril de 1523 daba un golpe a la economía de los señores de Villardompardo, confirmando una pragmática de los Reyes Católicos, que estos nunca habían hecho cumplir, por la que se suprimían los estancos del tinte y otros, haciendo alusión precisamente al nuevo señor, Fernando de Torres, quien "tiene puestos muchos estancos e imposiciones ansí en las tenerías y barros de los canteros y tiendas de oficiales como en otras muchas cosas" (MOLINA, 1983: 44). Este era entonces menor de edad, y no sabemos cuándo se haría cargo de forma efectiva del señorío, pero en 1526 él, o sus administradores, iniciarían el primero de una larga serie de pleitos para recuperar sus privilegios sobre los estancos (MOLINA, 1983: 44). Progresivamente, recuperaría influencia en la ciudad de Jaén, aunque hasta 1555/56 no consiguió un puesto de caballero Veinticuatro (RAMOS, 2002: 737, tabla III).

Otra cuestión es la de su relación con la corte. Hasta ahora se creía que esta se inició en época de Felipe II. Pero es posible que mucho antes se produjera una aproximación indirecta a Carlos V, a través de la reforma y enriquecimiento de la ermita dedicada a Nuestra Señora de Atocha en Villardompardo. Se ha considerado que esta advocación fue 'adoptada' como patrona por los Austrias, cuando la antigua ermita en Madrid fue cedida por Carlos $V$ a los dominicos, y sobre la que estos construyeron su convento. Y aparentemente será una de las devociones predilectas de Felipe II y de otros miembros de la dinastía (SCHRADER, 2006).

La ermita de Villardompardo estaba situada en un pequeño altozano, frente al castillo. Esta es una advocación extraña en la provincia y, que sepamos, solo se localiza en Villardompardo, donde ya aparece en 1511 (RODRÍGUEZ, 1986: 27), sin que conozcamos por el momento su origen. El 2 de enero de 1549, Fernando de Torres y Portugal concertaba con Francisco

\footnotetext{
7. D. Fernando y Da Beatriz de Luxán tuvieron tres hijos, uno muerto joven, Bernardino e Isabel. Al fallecer su marido, Beatriz se casó con García de Villaroel, Adelantado de Cazorla, el cual casó a Isabel con su hijo Juan, y a Bernardino entonces con 13 o 14 años con su hija Luisa. Pero este escapó y consiguió anular ese matrimonio (CUEVAS, ARCO, ARCO, 2001, apéndices: XIV-XV y LI).
} 
de Escalona el contrato y las condiciones para la realización de un quarto en dicha ermita (LÁZARO, 2003: 25). Más allá de las motivaciones puramente religiosas y locales, es posible que la actuación de Fernando de Torres pueda interpretarse como un intento de aproximación, más o menos sutil, hacia Carlos V, que hiciera olvidar definitivamente al monarca la rebelión de su padre. Ello probaría la existencia de contactos con la corte mucho antes de lo que se había creído.

No se han publicado datos sobre sus relaciones en esta, ni este es el objeto de este estudio, pero debió de integrarse desde muy pronto en una de las redes clientelares nobiliarias a las que hemos hecho alusión. Por ideología y por tradición familiar, ya que los Torres siempre habían estado enfrentados a la rama local de los Mendoza, es verosímil que Fernando de Torres se aproximase a los grupos conectados con el duque de Alba, lo que le permitiría acceder a algunos cargos. Quizá desempeñó algún puesto, antes de que le llegaran los cargos relevantes, que alcanzó a partir de 1565 . Desde entonces fue corregidor en el principado de Asturias y luego en Salamanca (1565-1568). El 12 de octubre de 1576 Felipe II le nombró conde de Villardompardo. Poco después conseguía el puesto de Asistente de Sevilla (15781583), siendo finalmente nombrado virrey del Perú (1586-1590). Luego regresó a Jaén donde moriría en 1592 (MOLINA, 1983: 54-60).

Frente a esta intensa actividad en el exterior, como administrador real, sus sucesores en el señorío, tanto su hijo Bernardino, muerto antes que su padre, como su nieto Juan de Torres y Portugal, el II conde (1592-1612), parecen haber permanecido todo el tiempo entre Jaén y Villardompardo, e incluso el último parece que se enterró en la ermita de la Virgen de Atocha, en esta última localidad.

Sus descendientes se asentaron definitivamente en Madrid, en el entorno de la corte, y el palacio de Villardompardo entró progresivamente en decadencia. El catastro de Ensenada señalaba a mediados del siglo XVIII que estaba parte de él arruinado, y a principios del siglo XX los edificios habían desaparecido, la planta baja de los lados este y norte se habían rellenado de escombros para aplanar el solar que fue convertido, durante un corto periodo de tiempo, en plaza de toros. A finales de dicho siglo la fachada daba acceso a un amplio solar (fig. 2), sobre el que sobrevolaban proyectos de urbanización que, afortunadamente, se frustraron.

\subsection{EL CASTILLO}

El análisis arqueológico del castillo medieval ha sido objeto de otro estudio (MONTILLA, NAVARRO, SALVATIERRA, 2021). Aquí nos ocuparemos de su transformación en palacio, pero antes veremos los elementos que perduraron. La fortaleza medieval era un trapecio irregular, con torres rectangulares en los ángulos suroeste (tres plantas más una en baja, ocupada por un aljibe) y sureste (desaparecida en el siglo XIX), una circular al noroeste de la que solo se conserva la base, y otra rectangular, maciza, al noreste, junto a la que se abría la puerta del castillo (fig. 4).

Los lados norte y oeste estaban protegidos por un amplio foso de unos $5 \mathrm{~m}$ de anchura y otros tantos de profundidad. Al sur el terreno bajaba con una pronunciada pendiente, existiendo un cortado al oeste, por lo que no hacían falta otras defensas en esos lados.

Las excavaciones han proporcionado una amplia planta que muestra numerosos elementos excavados en la roca, pertenecientes a la edad del cobre y a las ocupaciones romana y medieval, así como a las estructuras que podemos relacionar con el palacio. Para describir estas últimas, las hemos marcado en el plano, y se han indicado con letras los diversos cuer$\operatorname{pos}^{8}$ y otros elementos significativos (fig. 5).

8. Las principales estructuras han sido denominadas cuerpos o edificaciones, priorizando el hecho de que se adosaron entre sí. Es por otro lado el nombre que les daba el catastro de Ensenada, de forma que no se los considera edificios independientes. 


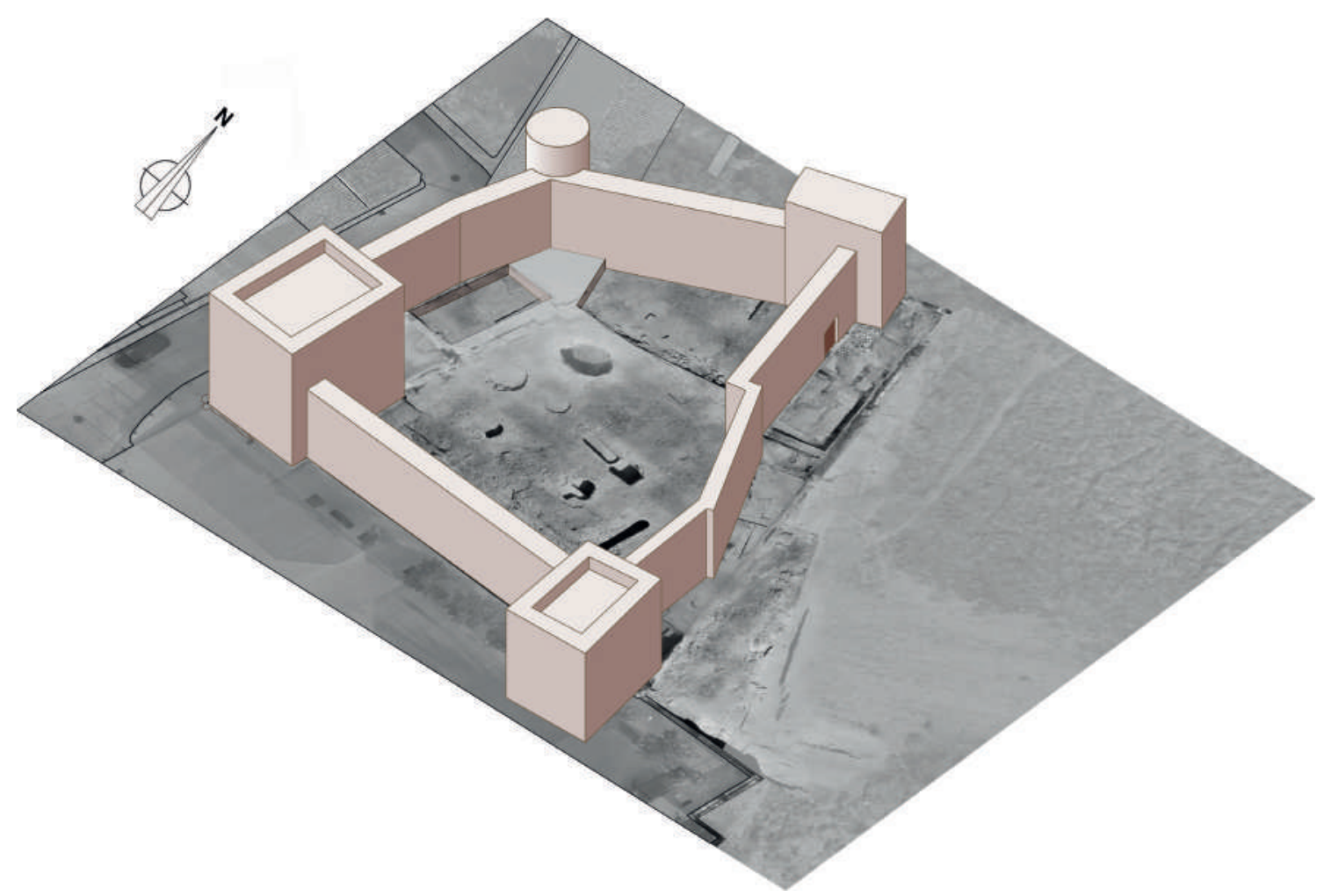

Fig. 4 Esquema del castillo Medieval

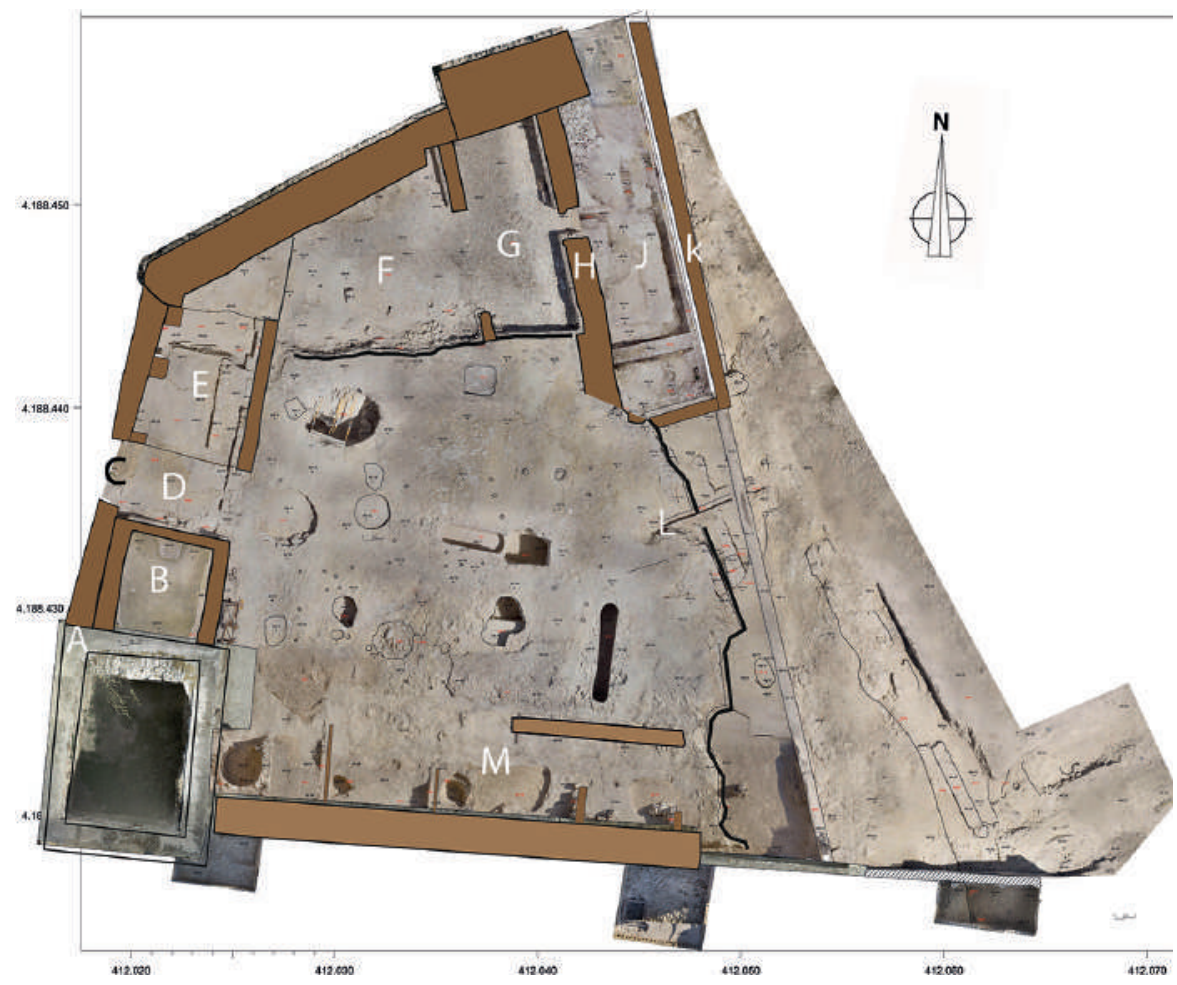

Fig. 5 Planta con las estructuras del palacio. A) torre, B) cripta, C) puerta, D) pasillo de acceso, E) galería del edificio oeste, F) caballerizas, G) sala este de las caballerizas, H) antigua muralla este del castillo, J) sótano del nuevo edificio, K) nuevo muro este, L) letrina y canal de evacuación, M) cuerpo sur. 
Aunque la planta se hizo mediante fotogrametría y es posible ver los detalles de muchos de esos elementos, el excesivo tamaño que requeriría la hacen inviable para una publicación como esta, en consecuencia, las diversas estructuras se ilustrarán con fotografías o dibujos específicos ${ }^{9}$.

\subsubsection{Las estructuras que se aprovecharon}

Varias construcciones del castillo medieval se integraron de forma diversa en la gran transformación que se llevó a cabo en el siglo XVI. La arqueología permite distinguir los elementos medievales de las reformas posteriores, a partir de los materiales, su ubicación y sus relaciones estratigráficas.

\section{A) Las murallas perimetrales}

Estaban realizadas con un grueso núcleo de calicanto, con piedras de pequeño y mediano tamaño, y un mortero realizado con guijarros de río, y protegido por espejos de mampostería irregular de mediano tamaño al interior y el exterior, que en el paramento oeste habían desaparecido por completo. Tenía una altura de casi $7 \mathrm{~m}$ en los lados oeste, norte y este ${ }^{10}$, pero solo de 1,75 m en el sur. La diferencia puede deberse a que las primeras, situadas en terreno accesible, fueron dotadas además del foso, de escarpas, que tenían que sujetarse en la mampostería. La sur no necesitaría esas defensas ${ }^{11}$. En esta última, por encima, se colocó un cuerpo de tapial. La existencia de un adarve por encima de este último indica que era una estructura medieval. A las murallas se adosaron los nuevos edificios o fueron integradas en los mismos. En el primer caso están las de los lados oeste y norte. En varios puntos al exterior de la última encontramos una combinación entre el mantenimiento y la renovación de los enfoscados; así, en distintos puntos se conservó un encintado medieval con esgrafiado, que dibujaba una decoración de hojitas, aunque en general domina el mortero de cal empleado en la fase posterior. Por su parte, las murallas sur y este quedaron integradas dentro de sendos edificios, aunque su nivel de conservación es muy diferente. La sur, está en buenas condiciones, la este, por el contrario, fue muy modificada; más adelante expondremos la distinta forma en las que fueron reutilizadas, lo que motivó su estado actual.

\section{B) La torre del homenaje}

Esta había sido construida en la segunda mitad del siglo XIII, pero destruida parcialmente en 1368, fue reconstruida a finales del siglo XIV, situándose en la planta baja un aljibe, reformándose la primera planta y levantando una segunda con tapial, utilizándose un mortero con piedras de pequeño tamaño (fig. 6 UE 2). En el siglo XVI se añadió una tercera planta, realizada también en tapial en el que destaca el uso de arena y un mortero con muchas piedras (fig. 6 UE 16). De esta forma la torre alcanzará los casi $20 \mathrm{~m}$ de altura que hoy tiene (fig. 5 , espacio A). Por lo que se refiere a los enlucidos, en la parte inferior de la primera planta se conservó en el interior y parte del exterior un encintado medieval similar al de la muralla norte, mientras que los superiores fueron recubiertos con mortero de cal.

\section{C) El corredor defensivo}

De la puerta de la antigua fortificación, situada en la muralla este, partía un largo y ancho pasillo que recorría el lado norte (fig. 5, espacios $G$ y $F$ ), presentando una ligera pendiente hasta llegar a unos $5 \mathrm{~m}$ del extremo oeste, desde donde se podía llegar al patio de

9. No nos referiremos aquí a las estructuras de los diversos periodos que se amortizaron, aunque al estar excavadas en la roca aparecen en la planta. Las referencias a las romanas y medievales pueden encontrase en el ya citado texto de MONTILLA, NAVARRO, SALVATIERRA, 2021.

10. Aunque en el lado este había desaparecido en gran parte, puede verse su composición en la roza de su encastre en la torre noreste (ver fig. 24).

11. Hoy al exterior de la muralla sur hay una plaza llana, pero aún se percibe en el perfil de la calle, y en fotos antiguas, la inclinación que debía de tener. 


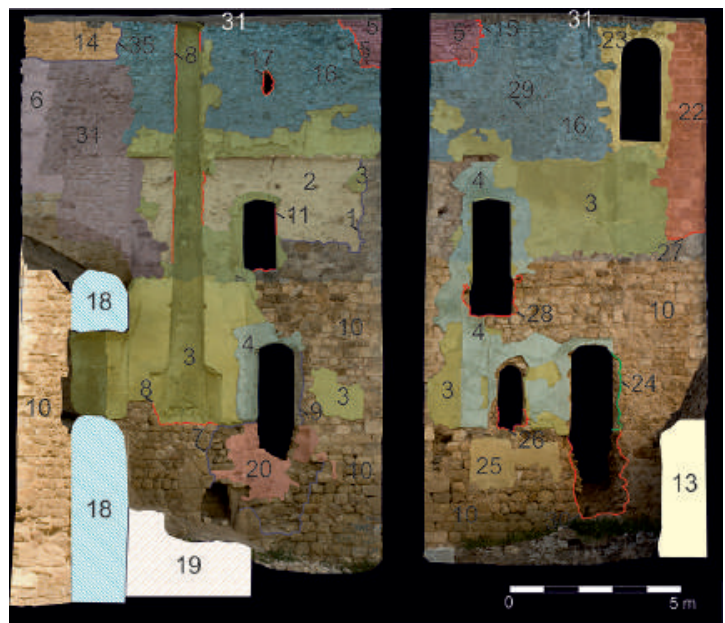

Fig. 6a Lectura de paramentos del exterior estey norte de la torre

\begin{tabular}{|c|c|c|}
\hline & UUEEE Lados este y norte de la torre & FASE \\
\hline 1 & Corte irregular recrecido $2^{\mathrm{A}}$ planta, introducción de tapial & 3 \\
\hline 2 & Paramento de taplal, con poca cal & 4 \\
\hline 3 & Modificación vanos. Mortero rosáceo con cal, $2 \mathrm{~cm}$. de grosor. & 6 \\
\hline 4 & Mortero de cal muy grueso de color blanquecino & 8 \\
\hline 5 & Reparación $3^{3}$ planta. Ladrillos unidos con mortero de cal & 8 \\
\hline 6 & Reparación $3^{3}$ planta Obra de sillería y verdugadas de ladrillo SE, E, N & 8 \\
\hline 7 & Corte irregular de la camisa exterior en su abandono & 9 \\
\hline 8 & Corte. Construcción de la chimenea & 6 \\
\hline 9 & Corte $1^{3}$ planta. Apertura de vano & 6 \\
\hline 10 & Obra de sillarejo & 3 \\
\hline 11 & Corte. Apertura de vano $2^{a}$ planta & 6 \\
\hline 12 & Corte. Recrecido esquina sureste & 8 \\
\hline 14 & Mamposteria irregular. Angulo esquina SE & 10 \\
\hline 15 & Corte. Reparación esquina superior norte & 8 \\
\hline 16 & Fábrica de pequeños mampuestos y ripios. Levantamiento $3^{9}$ pianta & 5 \\
\hline 17 & Corte. Calda de parte de la saetera. Abandono & 9 \\
\hline 18 & Zócalo mamposteria. Construcción cuerpo sur del palacio & 5 \\
\hline 19 & Calera & 8 \\
\hline 20 & Cubrición con un parche de la mampostería caída & 9 \\
\hline 21 & Obra con pequeños mampuestos y yeso. & 8 \\
\hline 22 & Esquina de sillares unidos por $405 \mathrm{~cm}$. de mortero. Reparación & 6 \\
\hline 23 & Mortero. Construcción de vano & 7 \\
\hline 24 & Corte. Apertura de vano con arco rebajado & 6 \\
\hline 25 & Revestimiento formando bóveda. Nuevo cuerpo & 6 \\
\hline 26 & Corte. Apertura de vano con arco & 4 \\
\hline 27 & Corte para arreglo de esquina noroeste & 6 \\
\hline 28 & Corte longitudinal, para la introducción de escalera & 7 \\
\hline 29 & Corte de sección circular, introducción escalera 3 Planta & 6 \\
\hline 30 & Corte. Caida de sillarejo y mampostería. Abandono & 9 \\
\hline 31 & Mampostería irregular unida con mortero. Restauración $3^{3}$ planta & 10 \\
\hline 32 & Cortes. Mechinales para el cuerpo adosado a la torre & 5 \\
\hline 35 & Corte lados oeste y sur. Reparación 3er cuerpo & 10 \\
\hline
\end{tabular}

Fig. 6b Relación de UUEE

armas; este acceso podía ser controlado desde este último y desde la muralla norte. Estos pasillos fortificados interiores eran un recurso defensivo que existía en otras fortalezas y que dificultaba la aproximación al núcleo de la misma (CASTILLO y CASTILLO, 2001: 724). En este corredor se ubicarán las caballerizas del palacio, como luego veremos.

\section{D) La cripta y la capilla}

En el castillo existe una cripta de enterramiento que se adosa a la cara norte de la torre del homenaje y a la muralla oeste, de planta

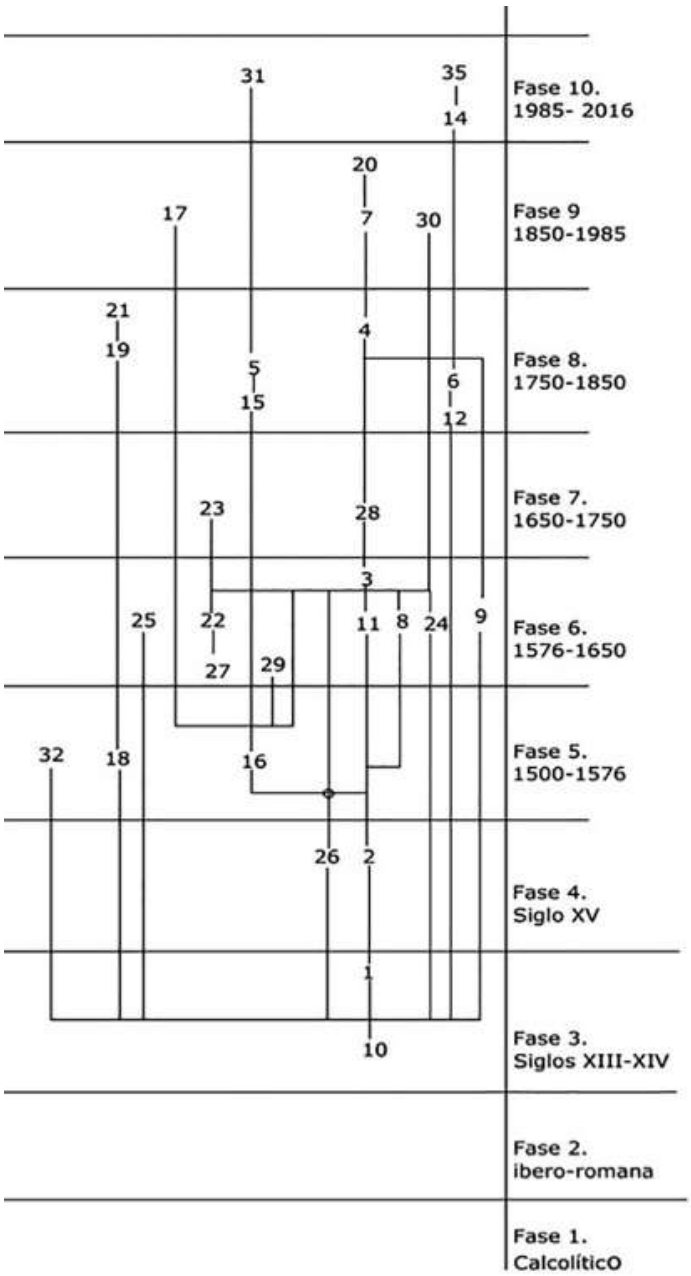

Fig. 6c Diagrama estratigráfico

rectangular y unas dimensiones de 6 por $5 \mathrm{~m}$ (fig 5, espacio B ; fig. 7). Estaba excavada en la roca y sobresalía apenas $1,50 \mathrm{~m}$ de la rasante del patio. En su interior tenía un amplio nicho localizado en el lado oeste y construido horadando la roca en la que se apoyaba la muralla de mampostería, mientras que adosados a la torre se construyeron otros de menor tamaño y realizados con una fábrica de mortero de cal con fragmentos de ladrillo. En el lado norte se encontraba la escalera de acceso levantada, al igual que los nichos, con argamasa de mortero de cal y cascajo, y de la que hoy solo se conservan los primeros peldaños. El espacio se cubría con una bóveda de ladrillo de la que aún se conserva su arranque.

Dada su posición, debió de construirse antes que la puerta, cuando la alberca ya estaba 

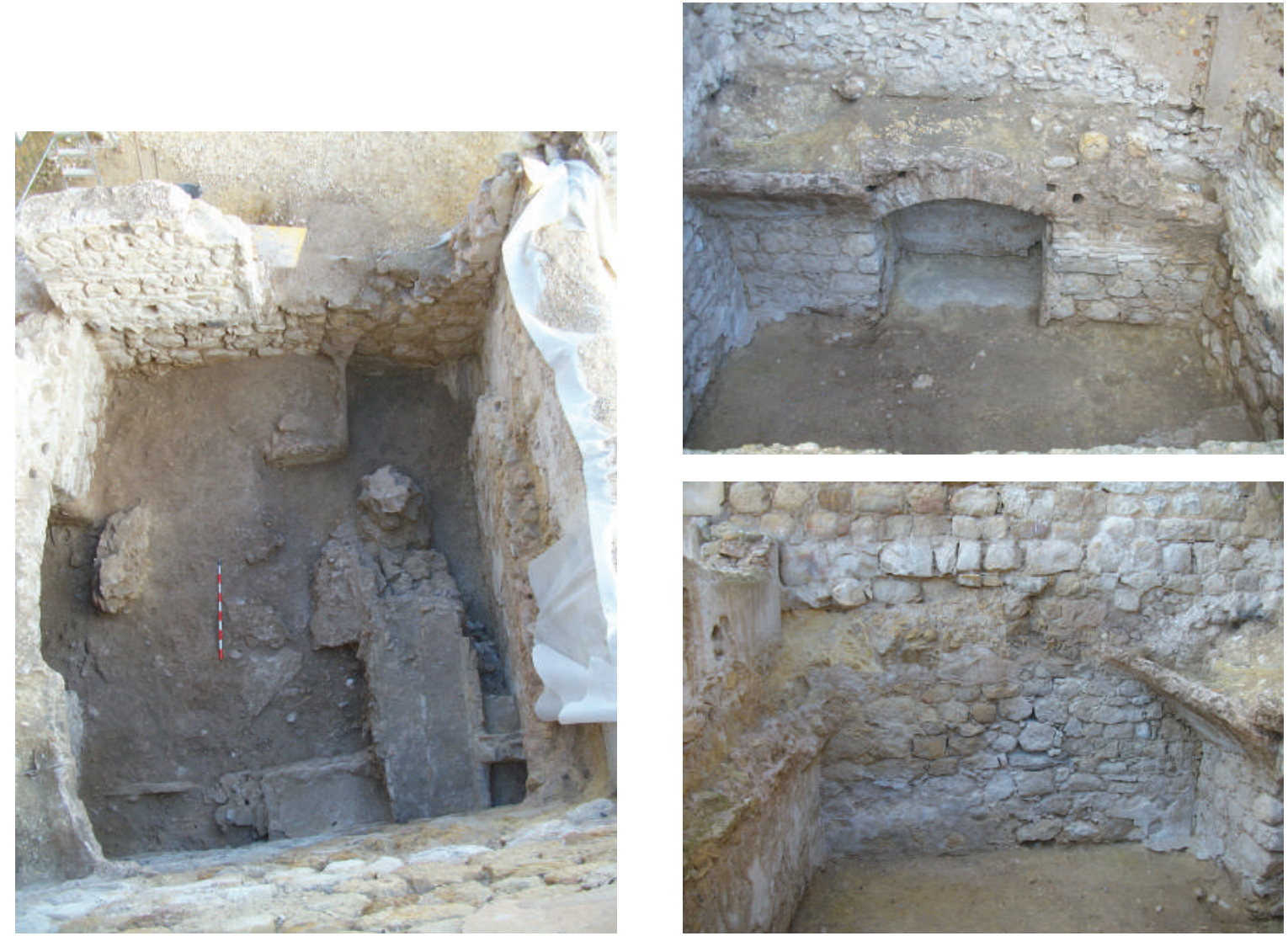

Fig. 7. Cripta. A) Perspectiva cenital, B) nicho oeste, C) Adosamiento a la torre y arranque de la bóveda

cerrada, disponiendo de un espacio suficiente para llevar a cabo cualquier tipo de ceremonia relacionada con la introducción de un difunto en la misma. Ello induce a pensar que cuando se abrió la puerta principal en el muro oeste la cripta ya no se utilizaba. Aunque podría haberse construido en los siglos XIII y XIV, es poco probable, ya que el castillo era del concejo de Jaén, no un espacio privado. Por lo que debió de ser levantada en el siglo XV por los Torres tras recibir el castillo en señorío ${ }^{12}$.

Tampoco sabemos quiénes se inhumarían en ella. Los Torres, al igual que otros nobles, disponían de una capilla en la antigua catedral de Jaén. Gonzalo Argote, a mediados del siglo XVI, da a entender que en ella se habrían enterrado todos los miembros del linaje, desde Pedro Ruiz, "en una capilla principal, á la mano derecha de la capilla mayor" (ARGOTE, 1991: 662). Esta la heredarían los Torres de Portugal y sería la misma a la que Don Fernando, el futuro conde, dotará en 1557 de un sacristán para que cuidase de ella, y que estaba situada "colateral a la del Santísimo Sacramento" (ARCO, 2007: 409). Y debe de ser también la que su segunda mujer, Da María Carrillo de Córdoba, cerró con una reja en 1588, cuando él era virrey del Perú, y que estaba situada "junto al sagrario, que alinda con la capilla de Don Po Ponce de León (...) la cuarta del muro del evangelio" (DOMINGUEZ, 1991: 8-9), y que les servirá de panteón. Toda esta zona fue demolida posteriormente al realizarse las obras de la nueva catedral (ALONSO, 2014: 47-71). Por tanto, no sabemos exactamente quiénes se enterraron realmente en la misma. Como hipótesis, es posible que en la cripta del castillo se inhumaran durante

12. Su cierre en el siglo XVI coincide tanto porque no hay noticias sobre las actuaciones de los primeros Torres de Portugal en el castillo, como porque en esa época volvió a reforzarse la costumbre de vincular los cementerios a las iglesias regulares, sobre todo desde el Concilio de Trento. 
buena parte del siglo XV miembros secundarios del linaje, parientes directos de los señores, hijos pequeños muertos en la infancia, etc. 0 incluso criados de especial relevancia. Lamentablemente carecemos de datos.

Entre la clave de la bóveda de la cripta y el forjado de la primera planta de la torre, donde estaba la puerta de entrada a esta, había un espacio de al menos $3 \mathrm{~m}$ de altura. Es espacio suficiente para crear una habitación rectangular, que tendría el mismo tamaño que la cripta. Pero no se han identificado posibles indicios de este, como rozas en la pared de la torre donde encastrasen sus muros, aunque los mismos pudieron estar simplemente adosados. La única prueba de que ahí hubo un edificio es que por encima se encuentra la puerta de la torre (fig. 6 UE 24), abierta a finales del siglo XIV, cuando en la planta baja de esta se instaló un aljibe y la puerta original, al este, fue clausurada (MONTILLA, NAVARRO, SALVATIERRA, 2021). Pudo tratarse de una capilla, ya que podemos presuponer que la cripta debía de ir acompañada de un lugar para la oración. Su techo quedaría ligeramente por debajo del umbral de la puerta de la torre, por lo que, de existir en época medieval pudo servir como patín, un elemento que reforzaba la defensa de las puertas (MORA-FIGUEROA, 2006: 154-155), y al que se llegaría desde el patio. Parece plausible que esta antigua capilla, si existió, se integrase en el palacio, y fuese a la que el catastro de Ensenada denomina oratorio en 1751.

\section{LOS CONSTRUCTORES Y HABI- TANTES DEL PALACIO}

Es a través de la arqueología como deben establecerse las fases constructivas del palacio y su cronología. Ya hemos definido las características principales de las obras medievales, y también, tratado de delimitar los espacios preexistentes antes de la construcción del palacio, todo lo cual nos servirá como punto de partida para determinar qué obras se llevaron a cabo y establecer la cronología de las actuaciones que convirtieron este castillo en palacio.

No obstante, como historiadores, consideramos que deben emplearse todas las fuentes disponibles, y la documentación escrita ayuda a afianzar y matizar la cronología. El castillo tuvo un uso claramente militar hasta el final de la guerra de Granada (1492). Puesto que las reformas implicaron la eliminación de buena parte de su capacidad defensiva, no es probable que se emprendieran antes de esa fecha. Pudo iniciarlas Teresa de Torres, pero esta tenía otras preocupaciones, y no hay evidencias de que visitara el lugar ni una sola vez, pese a lo cual algunas actuaciones podrían situarse en su época, aunque no hay pruebas claras. En general creemos que debieron de ser los Torres de Portugal quienes llevaron a cabo la mayoría, si no todas las reformas. No hay datos sobre actuaciones de los primeros señores, por el contrario, algunos documentos fechan diversas obras, que parecen relacionadas con la terminación del mismo (construcción de rejas, escudo de la portada, etc.) entre los años cuarenta y sesenta del siglo XVI. Por tanto, serían Fernando de Torres (1522-1592) y su primera mujer, $D^{a}$. Francisca de Carvajal y Osorio, quienes realizarían, o al menos terminarían, el palacio. Según sugieren las actas de bautismo de varios de sus hijos, tanto este matrimonio como su nieto, el II conde (15921610) y su segunda esposa, residieron con frecuencia en el palacio ${ }^{13}$. Por lo que se refiere al último, hay además noticias de que en diversas ocasiones intervino en los cabildos municipales y tomó decisiones importantes para el municipio, según las actas capitulares ${ }^{14}$. Y,

13. Archivo Parroquial de Villardompardo (APV) Para los hijos de Da Ma Carrillo, Carlos Ramírez http://condadodevillardompardo. blogspot.com. Para los de Da Polinia de Bazán, primer libro de los archivos parroquiales y firmadas por el "Maestro Cibantos", prior de la "Iglesia de esta Villa", C. Ramírez http://condadodevillardompardo.blogspot.com/.

14. Archivo Municipal de Villardompardo (AMV), Actas Capitulares. Comienzan en 1592. Las mismas recogen diversas intervenciones del conde en nombramientos de alcaldes y regidores de la localidad, aprobándolos o rechazándolos, como el 19 de enero de 1599. Carlos Ramírez, http://condadodevillardompardo.blogspot.com/ 
aunque parece que falleció en Jaén, donde hizo testamento ${ }^{15}$, se enterró en la ermita de la Virgen de Atocha ${ }^{16}$, frente al palacio. Ninguno de sus sucesores viviría en el palacio, por tanto, las obras que se ejecutaron posteriormente serían reparaciones y adaptaciones relacionadas con la utilización del espacio para otras funciones, principalmente agrícolas, pero no con su uso como palacio propiamente dicho.

\section{DESCRIPCIÓN Y RECONSTRUCCIÓN DEL PALACIO DE VILLARDOMPARDO}

En 1751, el catastro del marqués de la Ensenada proporciona la única descripción conocida del palacio. Puesto que este dejó de utilizarse como residencia por los condes prácticamente a principios del siglo XVII, esta debe de seguir reflejando en gran parte cómo era cuando se construyó, pero también recoger las adaptaciones a un uso exclusivamente agrícola, cuando los condes dejaron de mantenerlo como residencia:

"[...] tiene el citado conde unas casas palacio extramuros de la villa, que se componen de treinta $y$ seis varas de frente y las mismas de fondo, con un salón y dos cuartos, caballeriza seguida de sótano, y cocina en bajo. Segundo cuerpo, un corredor galería, ocho cuartos, tres cocinas, una sala y oratorio. Tercer cuerpo, tres cuartos, dos torres y en ellas tres cuartos, dos "pajeras" y sobre ellas tres cuartos y varios retretes, está mucho de él inhabitable, están también un cuarto que sirve de cárcel y otro de pósito, que no hay. Y en caso de alquilarse deberá ganar cincuenta ducados de renta anual y dista de la población veinte varas $[\ldots]^{\prime 17}$.

El palacio, por tanto, estaba al exterior de un recinto que rodearía la población. Hay otra documentación que confirma que la localidad estuvo amurallada ${ }^{18}$, aunque no sabemos cuándo se levantó esta cerca, ni su capacidad defensiva, y no descartamos que fuese una construcción tardía, que básicamente tendría funciones fiscales, en cuyo caso el muro exterior oeste del castillo debió de formar parte de la misma. Hasta ahora no se han identificado restos de ella con seguridad, aunque puede haber fragmentos entre las viviendas.

\subsection{Acceso y distribución}

El foso que rodeaba los lados norte y oeste del castillo se rellenó completamente a principios del siglo XVI, para ello se arrojó gran cantidad de material que, según el estudio inicial parece muy homogéneo, y pertenecería a este momento. La antigua entrada al castillo, al noreste, quedó como acceso a las caballerizas y otras instalaciones de servicio; al mismo tiempo, en el muro oeste, al norte de la cripta, frente a la población, se abrió un nuevo vano de acceso al recinto, de 3,40 m de anchura, para proporcionar una entrada más cómoda a este.

Posteriormente, a ese vano se le agregó la portada renacentista que aún se conserva (fig. 5, espacio C; fig. 8). Esta es de una gran sobriedad clasicista; realizada en piedra de cantería, se conforma por dos cuerpos: el inferior con elegante arco de medio punto moldurado, con grandes dovelas despiezadas embellecido por una arquivolta, y ménsula con decoración vegetal de acanto en la clave, que apea en pilastras de grandes dimensiones, coronadas por un sencillo trozo de entablamento a modo de capitel y rematadas a nivel de suelo por sus correspondientes basas; el segundo, asentado sobre una cornisa de sillares, moldurada, presenta en el centro un gran cartelón rectangular que alberga las armas de don D. Fernando de Torres y su primera esposa Da. Francisca de Carvajal y Osorio (NICÁS 1997: 424-425, lám. CXXXI.2). Flanquean este dos elegantes eses con vegetación de acantos roleados. Restos de otros motivos decorativos se aprecian en el lado izquierdo, y entre ellos destaca una cabeza desfigurada por la acción del tiempo.

15. Así lo señala Miguel Carrión, uno de los testigos incluidos el “Memorial del pleito...” 1657, p. 70.

16. Según documentación aún inédita, que nos ha mostrado C. Ramírez, Cronista Oficial de Villardompardo.

17. Archivo Histórico Provincial (AHP), Catastro del Marqués de la Ensenada, Libro Maestro de Legos, 1751, folio 113

18. A.M.V. Actas capitulares del 29 y del 30 de junio 1600. Ante una epidemia de peste se cierra el pueblo, dejando abierta solo la puerta junto al castillo, a lo que el conde se opone, y el Cabildo decide al día siguiente cerrar esta y dejar abierta otra. 


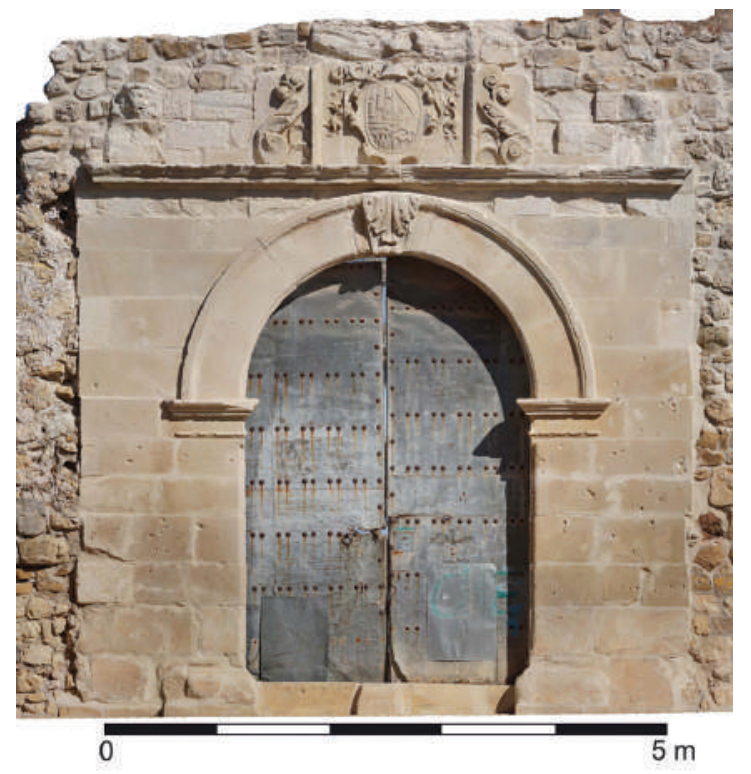

Fig. 8 Levantamiento fotogramétrico de la portada renacentista

El conjunto se remataba con un yelmo de hidalgo, vegetalizado, con sus correspondientes lambrequines ornados con cascabeles, a ambos lados del cual aparecen parte de los nombres de los fundadores ${ }^{19}$ (fig. 9).

Desconocemos el tracista que diseñó la portada o los canteros que la labraron. Quizá fue uno de los últimos elementos del palacio en ser construido. En cualquier caso, tuvo que colocarse antes de la muerte de Francisca de Carvajal, de la que se desconoce fecha, pero que debió de producirse en 1564 o antes, ya que de 1566 es el acta de bautismo del primer hijo de D. Fernando con su segunda mujer, $D^{a}$ María Carrillo de Córdoba ${ }^{20}$.

La portada daba acceso a un pasillo de 5,65 m de largo hasta el patio (fig. 5, espacio D), que quedó integrado en el edificio que se construyó adosado a la muralla oeste, constituyendo un verdadero zaguán, que daba acceso tanto a la planta baja de este edificio, como al patio, que articulaba el espacio, y en torno al cual se distribuían las diversas construcciones (fig. 10).

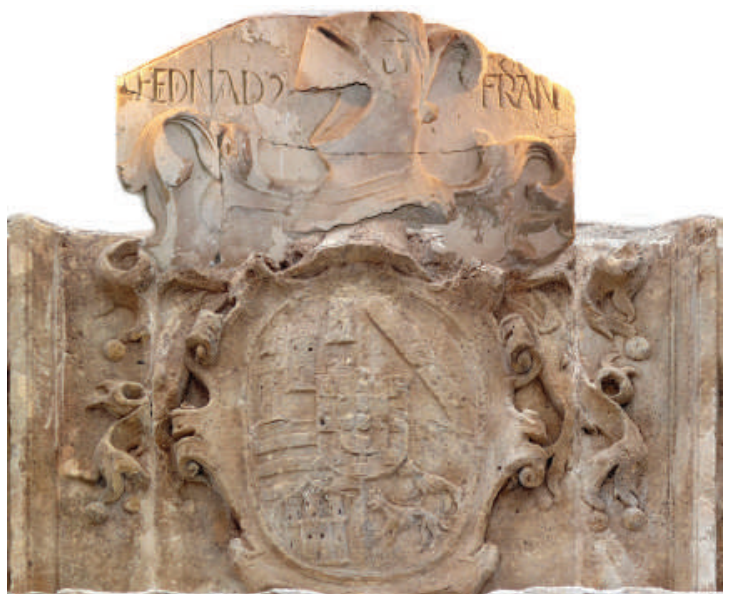

Fig. 9 Detalle del escudo y yelmo

Este zaguán está en rampa, debido a que el lado oeste presenta un desnivel superior a los $50 \mathrm{~cm}$ respecto al patio y al edificio sur.

Los datos arqueológicos disponibles para la reconstrucción que proponemos son escasos, pero suficientes. Dependiendo del desnivel de cada zona se han conservado parte de las plantas inferiores de los edificios, aunque es muy poco lo que sabemos de las superiores, que solo pueden deducirse a partir de la lectura de los paramentos de las murallas. Pero las modificaciones sufridas por estas obligan a realizar una lectura mediada por el principio de los hiatos y, por tanto, solo es posible una lectura parcial del palacio, y su reconstrucción hipotética.

\subsection{Los edificios en torno a la torre}

La parte principal del palacio se organizó en torno a la antigua torre del homenaje. A las cuatro caras de la torre se adosaron otras edificaciones, que se comunicaban a través de la misma. Desaparecidas estas, aún hay en la torre elementos que demuestran su existencia. Los más evidentes son los grandes vanos abiertos en sus caras, cubiertos con arcos

19. En la portada solo aparece la parte donde se apoya el casco, muy deteriorada. Hace unos años, el cronista de Villardompardo, Carlos Ramírez, localizó en el ayuntamiento un fragmento de caliza, procedente del castillo, que se corresponde con el casco. Dicho fragmento se ha unido al escudo existente como imagen 9.

20. Archivo Parroquial de Villardonpardo, Carlos Ramírez, http://condadodevillardompardo.blogspot.com/ 


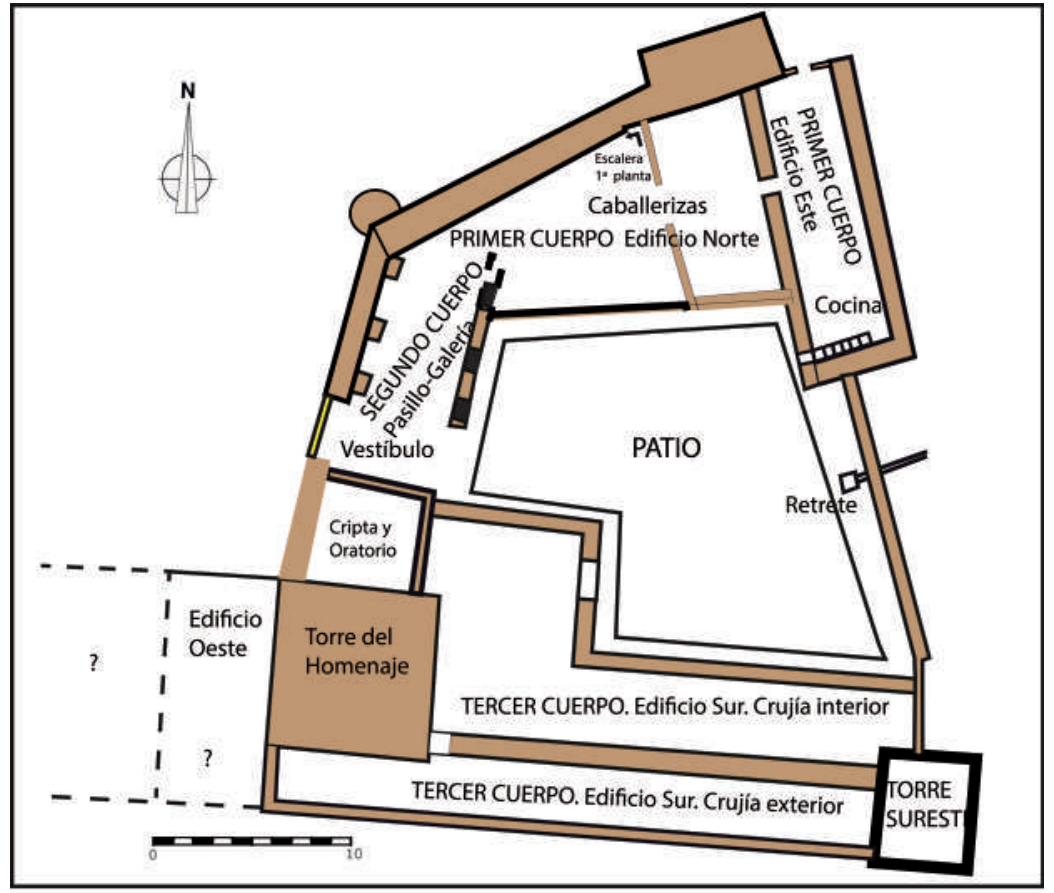

Fig. 10 Hipótesis de reconstrucción de la planta baja del palacio, según la arqueología y el catastro de Ensenada

escarzanos. Tradicionalmente se ha considerado que eran ventanales, que reforzaban el papel residencial de la torre. Pero en realidad son los vanos que comunican las plantas de esta con las de las nuevas edificaciones, lo que se comprueba por la existencia de escalones en los abiertos en la cara norte (fig. 11). Probablemente el desnivel entre las plantas de las alas oeste y norte, unidas por la torre del homenaje, se produjo por la adaptación de aquellas a las diferentes cotas existentes, ya que la planta baja del lado oeste tenía un nivel de rasante $50 \mathrm{~cm}$ por debajo del que presentan la plaza de armas y el ala sur.

Además de los vanos, hemos podido estudiar algunos elementos y correlacionarlos con las descripciones del catastro de Ensenada, identificando los cuerpos que señala con las distintas edificaciones documentadas por las excavaciones y la arqueología de la arquitectura.

\subsubsection{El cuerpo oeste}

Lo identificamos con el segundo cuerpo del catastro, que estaba compuesto por: un corredor galería, ocho cuartos, tres cocinas, una sala y oratorio (figs. 12 y 13).

El edificio se adosó a la cara norte de la torre y tuvo que adaptarse a la existencia previa de la cripta y la capilla. La primera ya habría dejado de utilizarse puesto que, tras las normas establecidas en el concilio de Trento, las inhumaciones se realizarían en el cementerio vinculado a la iglesia de la localidad. En cualquier caso, las excavaciones mostraron que todos los nichos estaban vacíos, y casi destruidos. Por otra parte, como hemos apuntado, la capilla puede ser el oratorio citado en el catastro.

A continuación de la cripta se encuentra el pasillo de acceso desde la puerta principal hasta el patio (fig. 5, espacio D; fig. 14) salvando una pendiente de unos $50 \mathrm{~cm}$, y que quedó integrado en este edificio como zaguán. El mismo muestra un empedrado en el que se distinguen diferentes facturas, con piedras y guijarros de distintos tamaños, que muestran los numerosos arreglos que debieron de realizarse en este espacio muy transitado a lo 


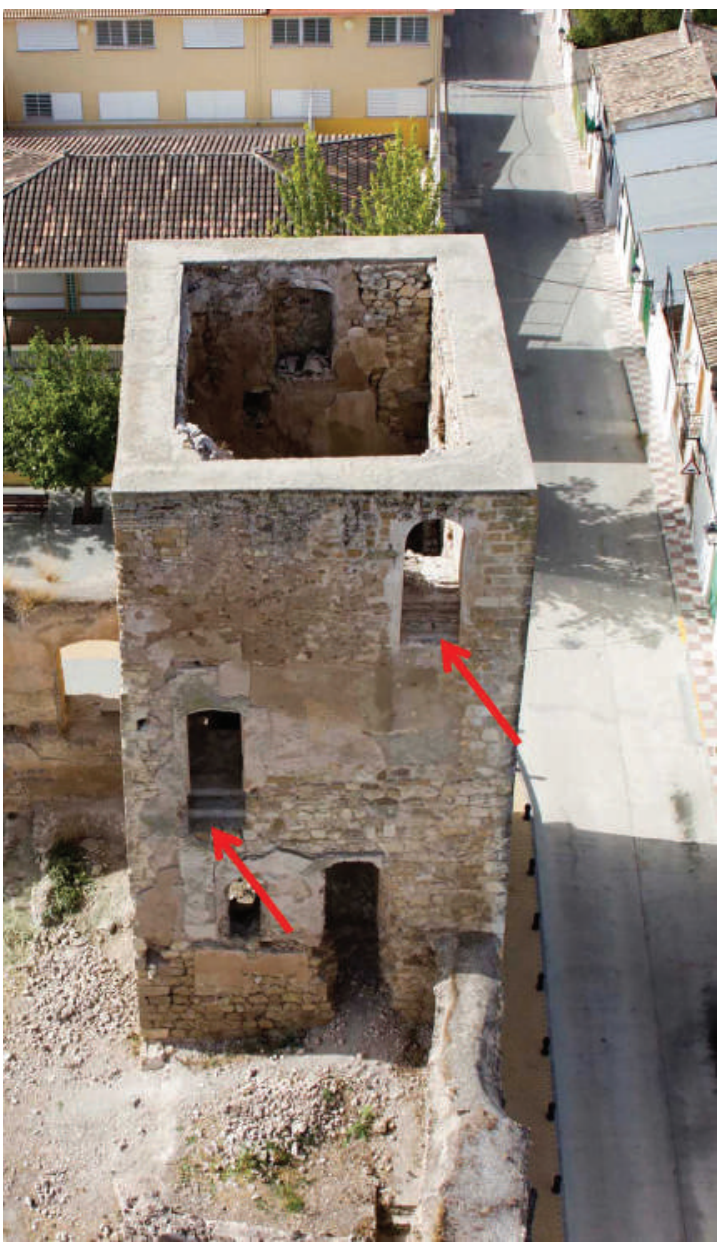

Fig. 11 La torre con escalones en los vanos de la cara norte. El acceso inferior es la puerta de la torre a la $1^{a}$ planta, sobre el aljibe (dentro), situada sobre la cripta-oratorio (fuera).

largo del tiempo. Al norte de la puerta (derecha) puede identificarse el corredor galería que ocupaba el resto de la nave inferior (fig. 5, espacio D; fig. 14). Tenía una anchura de unos 5,65 $\mathrm{m}$, con un pavimento en spicatum ${ }^{21}$, para colocar el cual que se amortizó una gran alberca existente en este espacio en época medieval. Adosados a la muralla se conservan dos pilares realizados con sillares escuadrados, habiendo existido probablemente un tercer pilar junto a la puerta, estos se corresponden con sendas huellas en el lado este. Por tanto, habría tenido dos vanos que darían luz desde el patio. Este espacio pudo ser utilizado como tribuna, desde donde los señores o las damas podían contemplar, con el adecuado distanciamiento, los espectáculos que pudieran desarrollarse en el patio ${ }^{22}$. No sabemos si la cubierta de la galería se apoyaría en amplios arcos, como sugieren los pilares, o en vigas.

Porencima de estagalería habíatres pisosque comunicaban con la torre, como demuestran los escalones situados en los vanos de esta. Desde la primera planta se accedería por el sur a la torre y a la capilla/oratorio, aunque esta quizá estuviese en un plano más bajo y se requiriese una corta escalera. Por encima de esta planta había otras dos. En el extremo noroeste de la galería parece que había una escalera, de la que solo quedaban indicios, que quizá comunicara privadamente esas tres plantas.

\subsubsection{El cuerpo sur}

La investigación arqueológica muestra que en el lado sur había cuatro estructuras. La más evidente es la torre del homenaje, con una planta baja ocupada por el aljibe, y tres en altura. Al oeste de esta torre estaba la segunda edificación, al exterior del recinto actual, hoy desaparecida y de la que desconocemos su tamaño, aunque sí sabemos que tendría tres plantas, una coincidente con el aljibe de la torre del homenaje, y otras dos que comunicarían con esta por sendos vanos. Estos se perciben en algunas fotos antiguas (fig. 2); fueron cegados al exterior en la restauración de 1987, pero siguen siendo visibles por el interior. La tercera planta de la torre del homenaje tiene en este lado una amplia ventana, que descarta que el edificio llegase a esta altura.

En el extremo sureste del recinto había otra torre, también desaparecida, pero que aparece delimitada en los planos de finales del siglo XIX, y que según el catastro de Ensenada tendría tres plantas. Esta torre y la del homenaje estarían unidas por la cuarta edificación, que ocuparía toda la longitud de la muralla sur del castillo. Esta tenía dos crujías paralelas, construidas a

21. En los siglos XVII o XVIII este espacio se dividió en una habitación y un muro, colocando este a 1 m aproximadamente del cierre este del edificio. Igualmente se creó un nuevo acceso desde el zaguán.

22. En un momento muy posterior, probablemente cuando el edificio solo tenía funciones agrícolas, se dividió el espacio, colocando un muro que creó una habitación al oeste y un pasillo de acceso al este. 


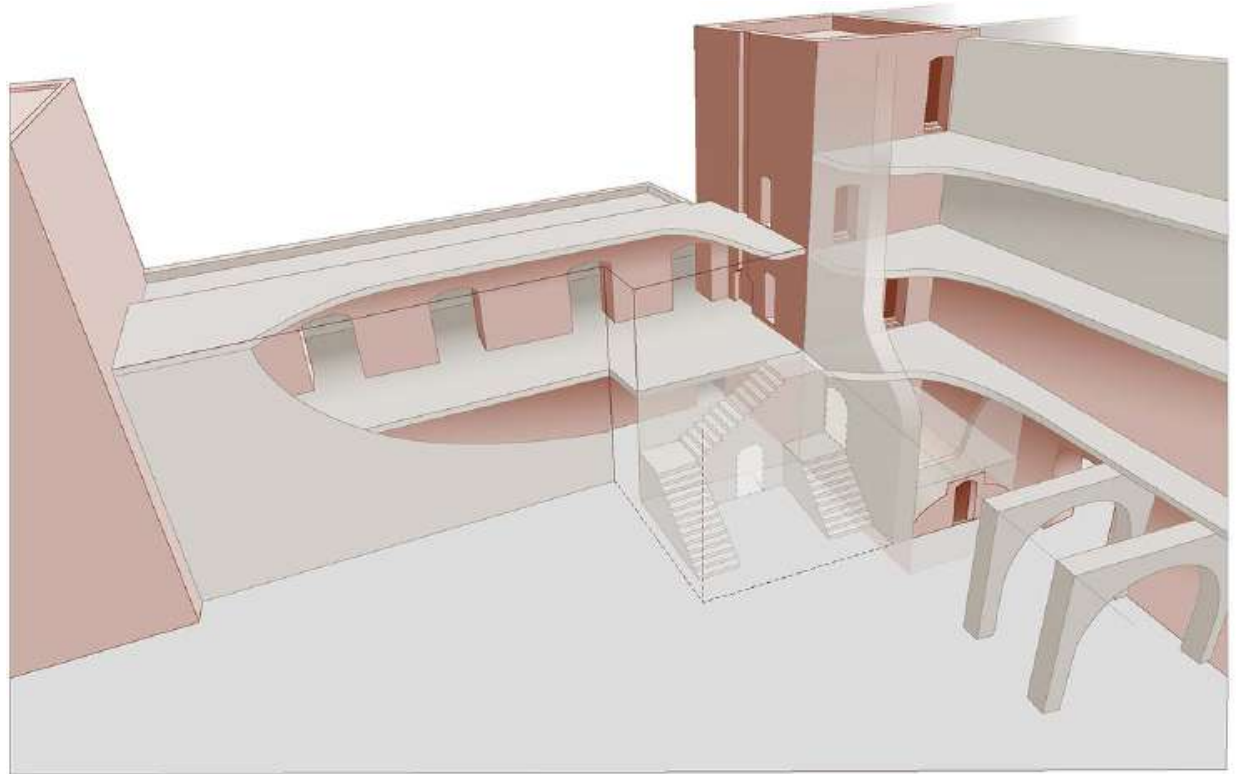

Fig. 12 Reconstrucción de los cuerpos sury oeste adosados a la torre del Homenaje (Dibujo de M. Salvatierra)

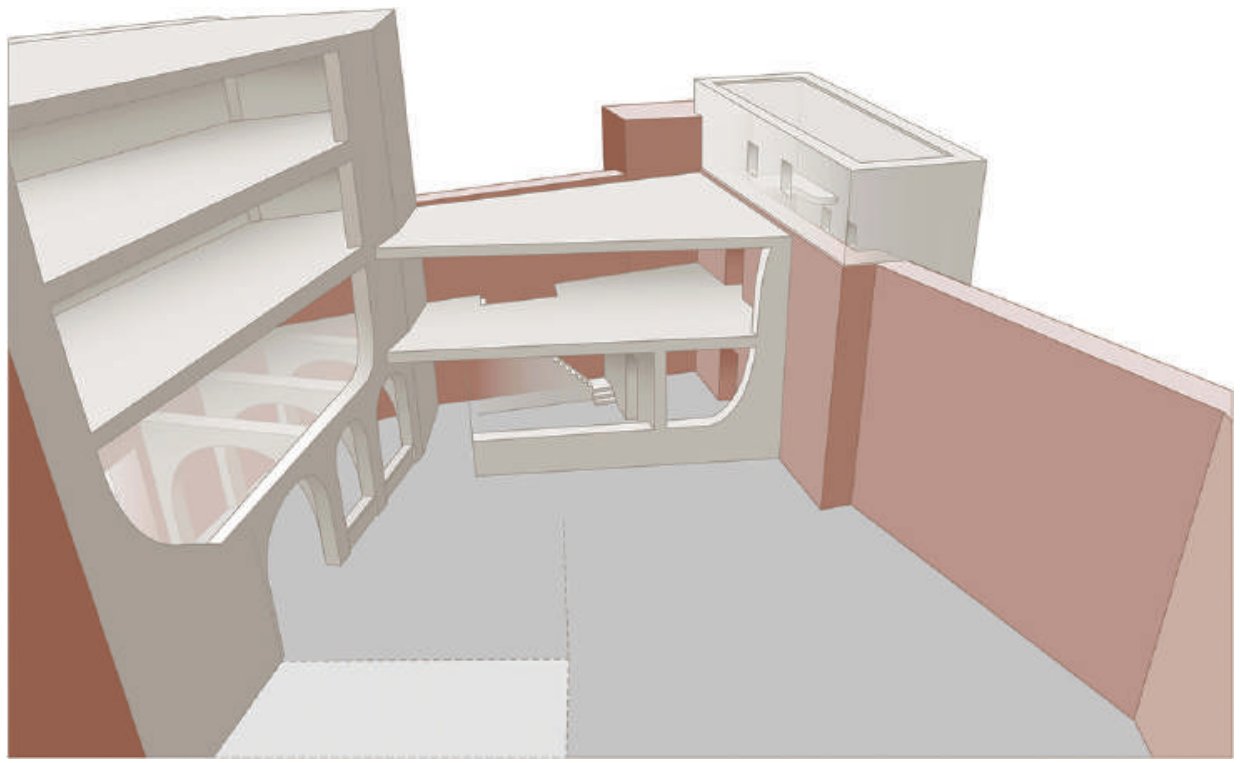

Fig. 13 Reconstrucción de los cuerpos oeste y norte adosados a la torre del Homenaje (Dibujo de M. Salvatierra)

ambos lados de aquella, cada una de las cuales tenía al menos dos plantas (fig. 12), según las evidencias que examinaremos a continuación.

En algunas imágenes antiguas (ROMERO DE TORRES, 1915, III. 234-236, foto IX. 151) se puede apreciar el que quizá era el último resto del muro de cierre de la crujía exterior, el cual se prolongaba por el lado sur de la torre (fig. 15). Las dos crujías se comunicaban en planta baja por un único paso, cubierto con bóveda de cañón hecha de mortero de cal y pequeñas piedras $^{23}$ (fig. 16).

En el interior, la construcción de un podio para el graderío de la plaza de toros preservó la

23. Se ha restaurado colocando un arco de mampostería en la roza existente. 


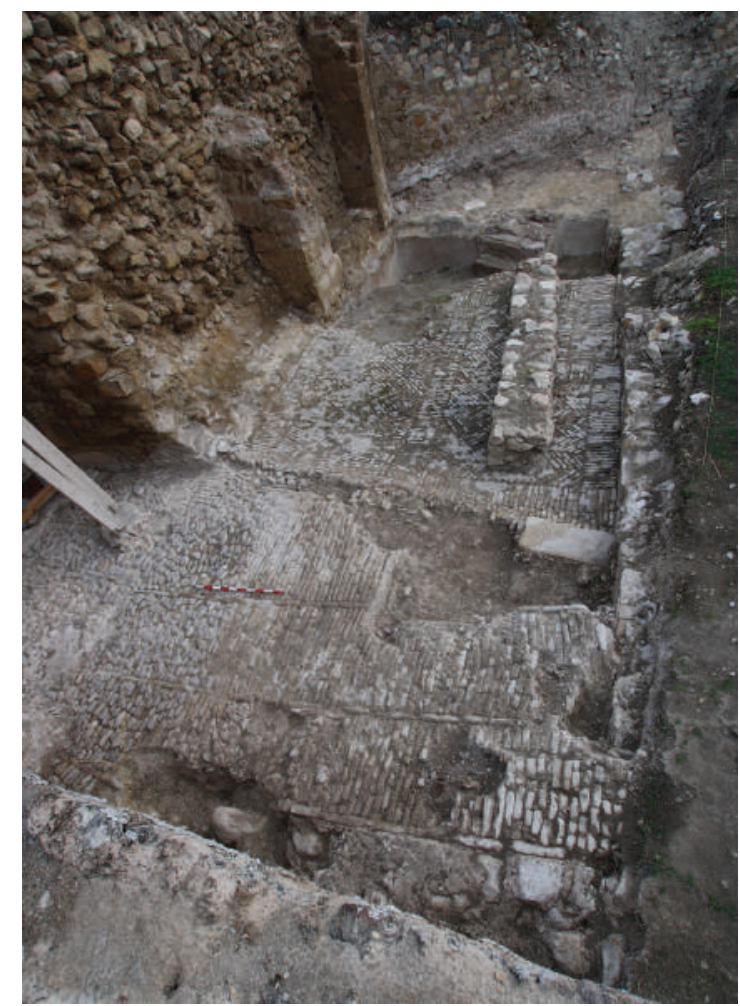

Fig. 14 A la izquierda, el acceso desde la puerta, con una inclinación oeste-este. A la derecha de este, la galería, con el pavimento en spicatum. En el otro extremo de esta se observa la ruptura del mismo. En esa zona estaba muy dañado y se retiró para excavarlo, poniendo al descubierto la estructura de una alberca anterior

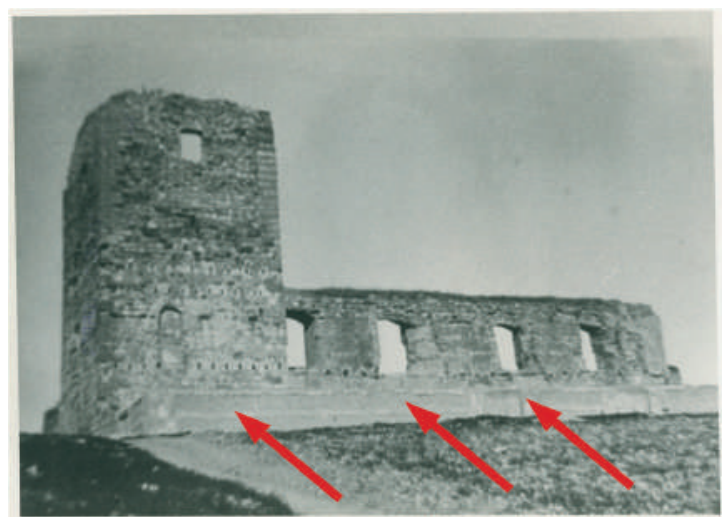

Fig. 15 Muro visible en fotos de principios del siglo XX. Quizá los restos del paramento de cierre de la crujía exterior sur parte inferior de la nave, existiendo divisiones hechas con tabiques muy delgados de mortero de cal y guijarros, y en el suelo amplios huecos para la introducción de tinajas (fig. 5, espacio M; figs. 17a y 17b). Es probable que estos elementos, sin duda vinculados a un uso agrícola, sean tardíos, al igual que la división de la galería oeste a la que ya hicimos referencia ${ }^{24}$.

La antigua muralla muestra que en el tapial de la primera planta (figs. 15 y 18, UE 134), se abrieron cuatro grandes vanos cubiertos por arcos escarzanos (UUEE 120 y 121), de los que uno, situado al este, ha desaparecido hoy casi por completo. Estaban situados por encima de las cajas de las vigas que debían soportar el techo de la planta baja y el suelo de esta primera (UUEE 135 y 136).

Al igual que en el caso de la torre creemos que no eran ventanas, sino que se trataría de vanos que comunicaban las dos crujías. Es posible que se crease un gran salón con dos naves paralelas, o que la interior fuese el salón, y en la exterior hubiese habitaciones, pero los indicios para defender una hipótesis u otra son escasos. En el paramento interior no hay huellas de que esa nave hubiese estado compartimentada; respecto a la exterior, la restauración de 1987 regularizó el muro eliminando todo rastro de las divisiones que pudieran haber existido. Lo único que se ha podido establecer sobre estos espacios es que las dos naves comunicaban con la torre por los lados este y sur respectivamente, que, como veremos más adelante, el techo de las dos crujías estaba a alturas diferentes, y que la crujía interior se dotó de una chimenea.

Esta se talló en la cara exterior de la torre, donde aún se aprecia su estructura y su tiro (fig. 19). Respecto a la misma, Bonet Correa señala que en la época estas aún eran excepcionales en España (BONET, 2018: 7). Los estudios que se han hecho al respecto, se basan por lo general en grabados o en las pocas que aún se conservan, pero, en nuestro caso, es su

24. Estos elementos se han preservado, al reconstruirse el techo de esta nave, para acceder a la torre. 


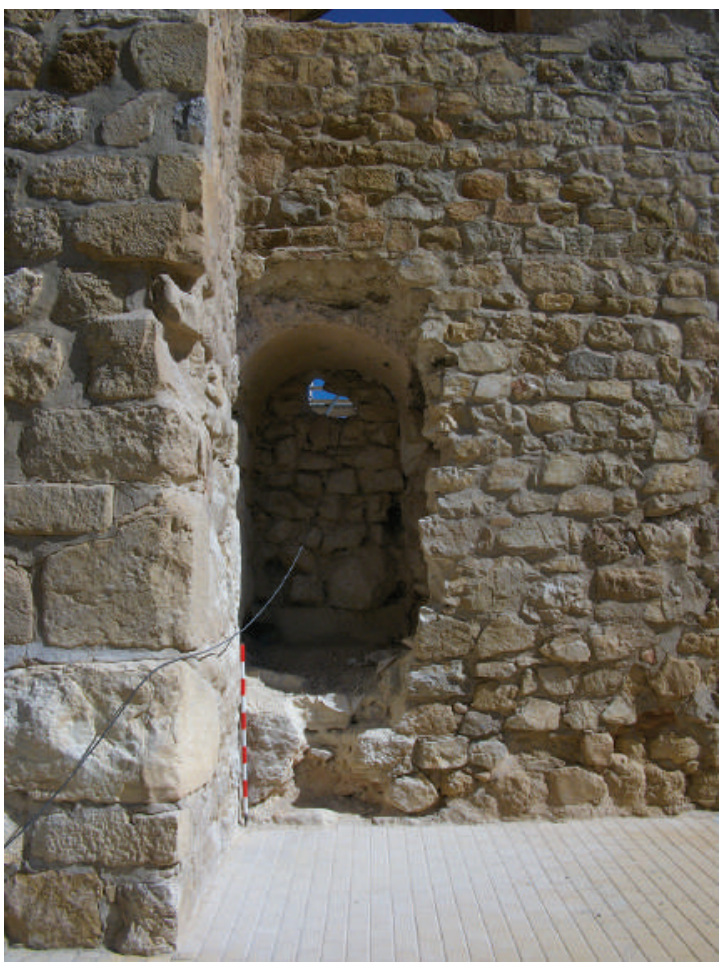

Fig. 16 Comunicación entre las dos crujías del lado sur con bóveda de medio cañón.

huella en la torre lo que demuestra su existencia. Tenía un tiro de unos $15 \mathrm{~m}$ de altura, aunque no sabemos cuánto sobresalía por encima. Ignoramos cuál era su remate. Bonet Correa apunta a algunas chimeneas de la época, que se levantaron con materiales pobres y de poco valor artístico. Ignoramos cuál fue la situación aquí, ya que, aunque la estructura del edificio parece en general pobre, tanto la portada, como las pocas referencias que se conservan de las rejas de algunas ventanas indican que sí hubo un gasto importante en diversos elementos que debían ser vistos al exterior.

Este autor señala que, según Sebastián Serlio, las campanas italianas eran de forma piramidal o cónica invertida, mientras que las francesas estaban compuestas por un paralelepípedo vertical, y que la salida de humos de las primeras era de tendencia circular o poligonal, y la de las francesas era rectangular (BONET, 2018: 12). Aunque obviamente se refiere a campanas adosadas a los muros, y en cuanto al tiro, a la parte alta, por encima del tejado, es evidente que la cámara de Villardompardo es un paralelepípedo, mientras que

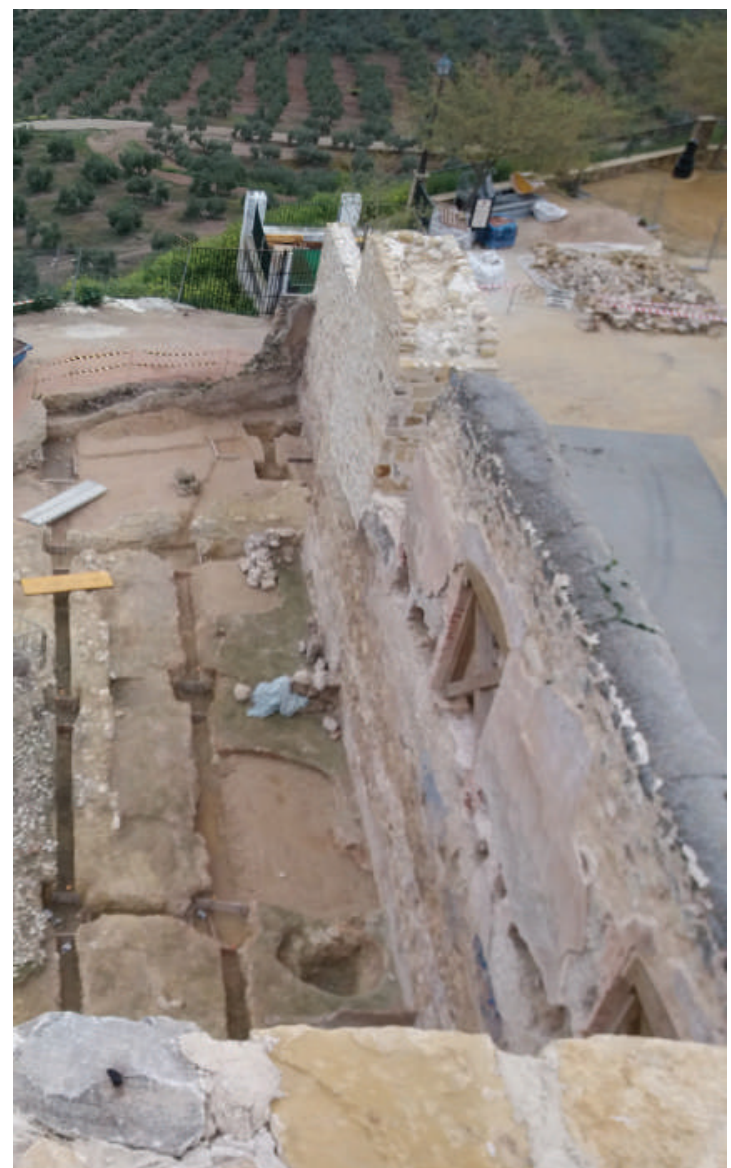

Fig. 17a Planta baja de la crujía interior del lado sur. Se aprecia el hueco para una gran tinaja

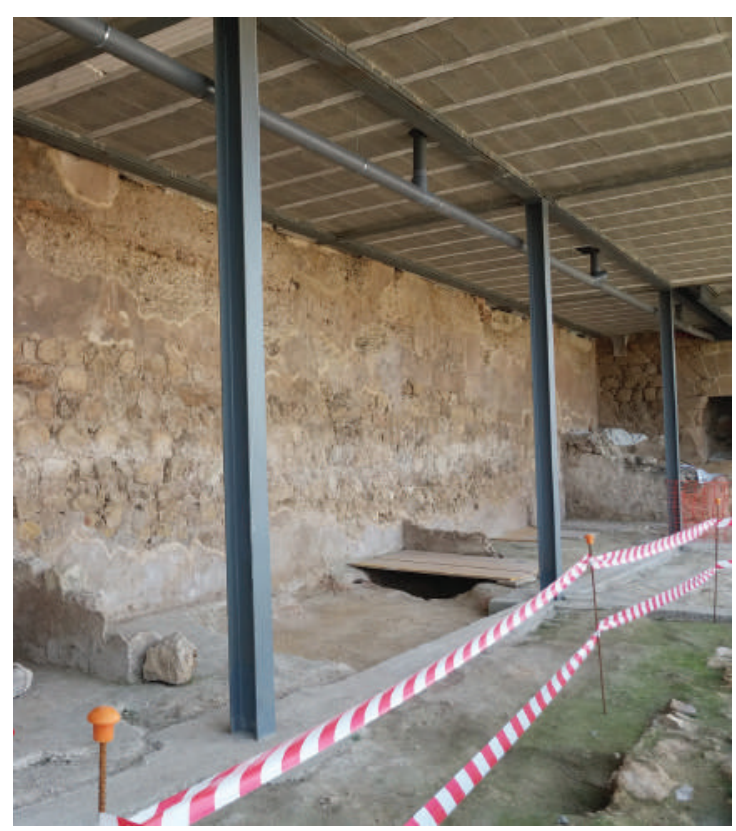

Fig. 17b Planta baja crujía interior del lado sur durante el proceso de restauración de esta nave 

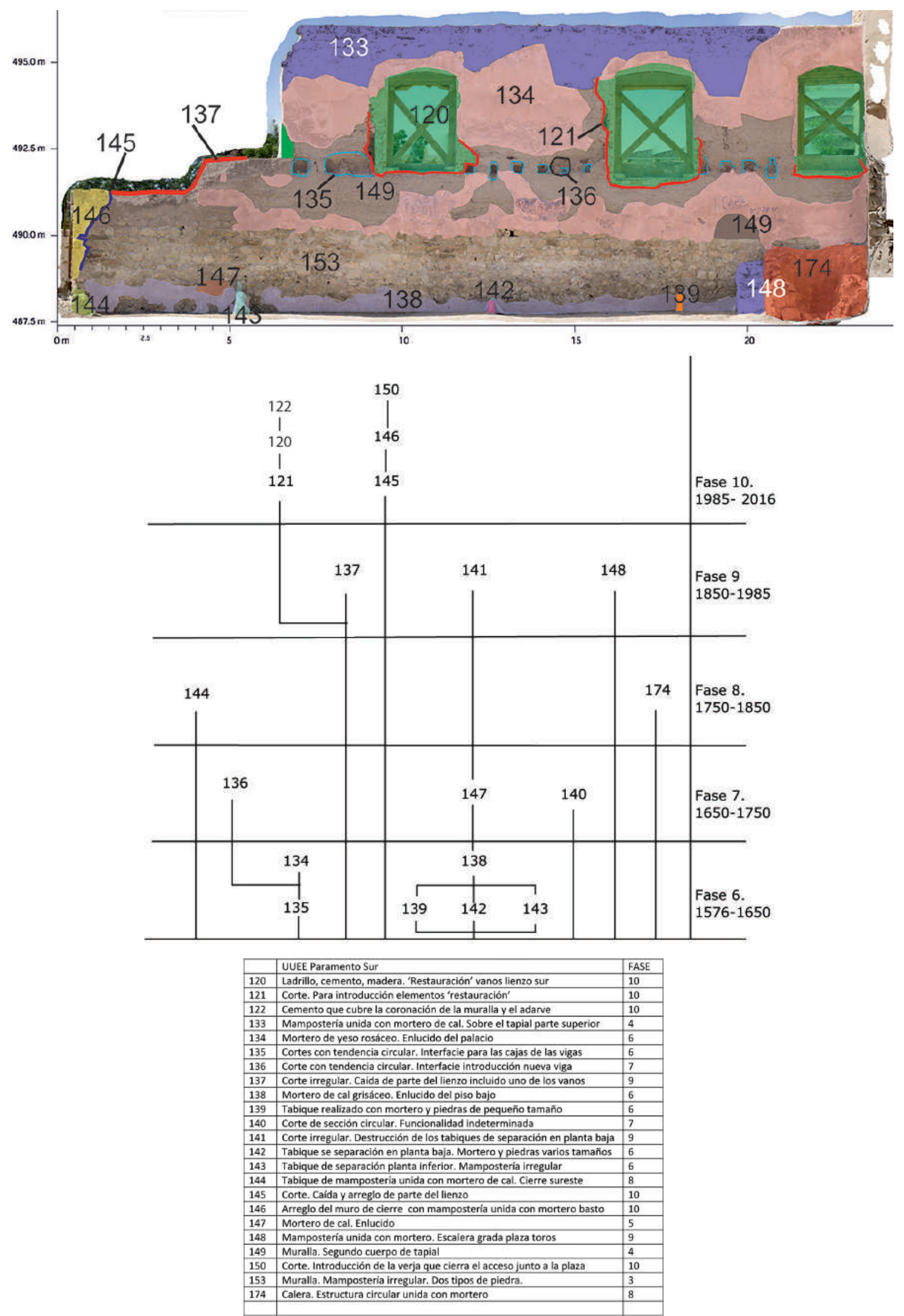

Fig. 18 A) Lectura del paramento sur interior. B) Relación de UUEE. C) Diagrama estratigráfico 


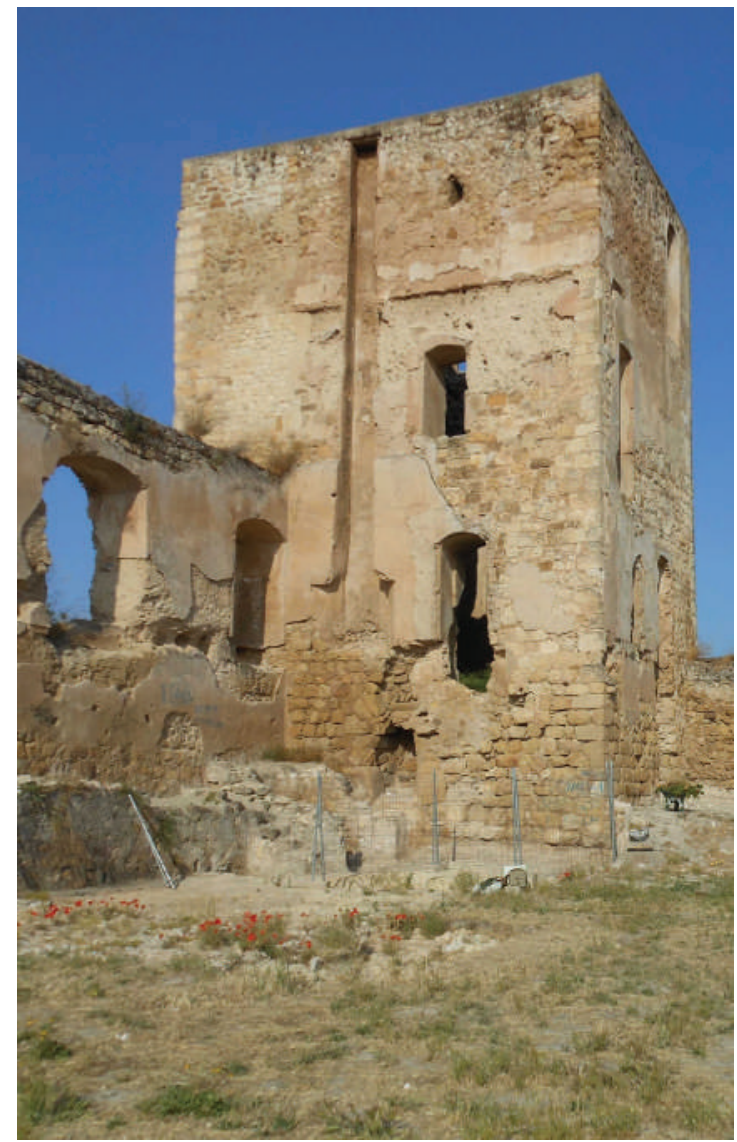

Fig. 19 Lado este de la torre y muro sur. En este último se aprecian dos de los vanos que comunicarían las crujías. En la primera, la chimenea, $y$ vanos de acceso a las plantas $2^{a}$ y $3^{a}$ de la torre

el tiro tiene una clara sección rectangular, aunque posiblemente era más fácil tallarlos así en el muro de la torre.

Por encima de la parte superior del muro de tapial corría un adarve (figs. 20 y 21) que en época medieval tendría pretiles tanto al interior como al exterior, como existían en muchos otros castillos. Se conserva el pretil interior, recubierto de mampostería irregular al exterior (fig.18, UE 133) y de unos $35 \mathrm{~cm}$ de grosor, sobre el que apoyaría el forjado de la crujía. Esta hipótesis surge del hecho de que no se han encontrado huellas de mechinales a lo largo del muro, y de que debía de existir un suelo por el que acceder al vano de la tercera planta de la torre. Por el contrario, el pretil exterior debió de ser eliminado y el adarve

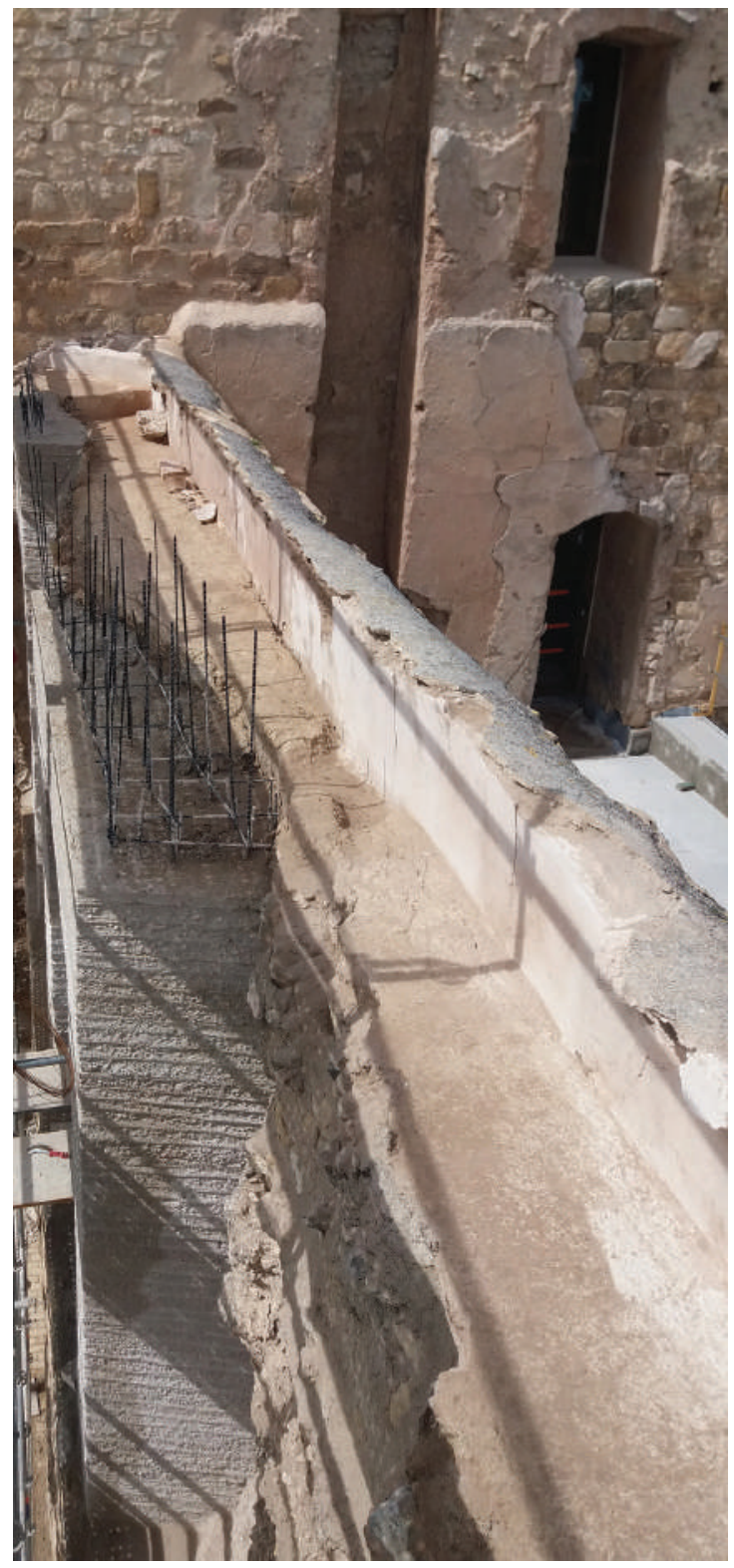

Fig. 20 Adarve desde la torre. El pretil, que fue cubierto de cemento en la restauración del año 1987 modificado, prolongando su suelo con el techo de la crujía exterior ${ }^{25}$. Esto implica, como ya avanzamos, que los techos de las dos crujías estuvieron a distinta altura, lo que a su vez explica la existencia de unos escalones en el extremo oeste del adarve, junto a la torre, que salvaban el desnivel (figs. 22 y 23).

Llama la atención que este edificio solo tuviese dos plantas, frente a las cuatro del situado al oeste. Podría suponerse que el vano

25. Es cierto que tampoco hay cajas de vigas que apoyen esta hipótesis, pero en este caso debido a la completa 'restauración' del paramento exterior de la muralla a la que ya hemos hecho alusión. 


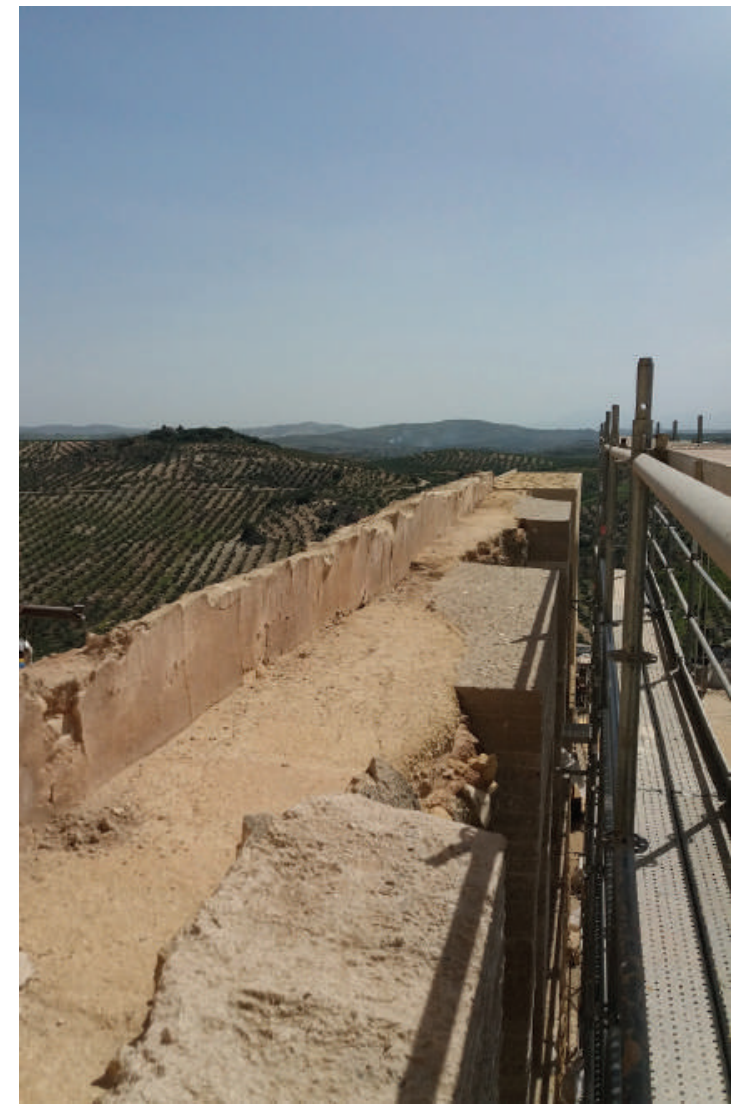

Fig. 21 Adarve. La apertura y restauración de los vanos lo eliminó en parte

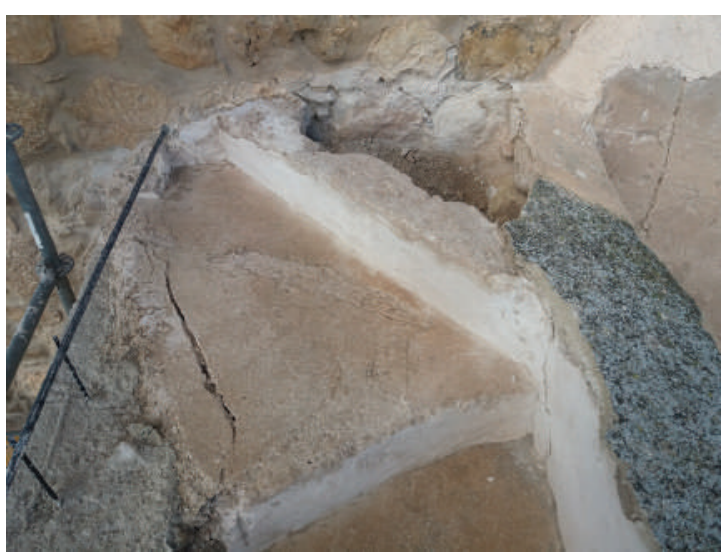

Fig. 22 Escalones entre los dos planos de los techos de la $1^{a}$ planta

de comunicación de la 'terraza' con la torre se debiera a la existencia de otro cuerpo, del mismo modo que los escalones, realizados con mortero. No obstante, no disponemos de elementos estructurales que confirmen la existencia de otras alturas. El pretil del adarve, con solo $35 \mathrm{~cm}$ de anchura es demasiado estrecho como para suponer que se elevó para sostener los dos cuerpos, y no hay huellas de pilares que soportasen los forjados a los lados de la muralla, ni en el adarve. Tendrían que haberse empleado vigas de grandes dimensiones, superiores a los $10 \mathrm{u} 11 \mathrm{~m}$ de longitud para ello. Es por supuesto factible, pero no hay evidencias.

Según el catastro de Ensenada el tercer cuerpo tenía: tres cuartos, dos torres y en ellas tres cuartos, dos "pajeras" y sobre ellas tres cuartos. Creemos que puede identificarse este cuerpo con las estructuras descritas. Los primeros tres cuartos corresponderían al segundo edificio, existente al oeste del recinto. Las dos torres, la del homenaje y la sureste, que tendrían tres plantas-cuartos cada una ${ }^{26}$. Y en el edificio central estarían las dos pajeras y sobre ellas tres cuartos. La descripción es del siglo XVIII, cuando las funciones agrarias posiblemente se habrían extendido por la planta baja de los distintos edificios, y quizá estas se empleasen para el almacenaje y como caballerizas, lo que explicaría la instalación de una pajera en cada una de ellas. Los cuartos se situarían en las otras plantas. Quizá la referencia a tres cuartos implique que existían tres plantas, una por cuarto, que podían o no estar divididas, o a divisiones de distinto tipo.

Por otro lado, la descripción es excesivamente escueta, no se mencionan las dos crujías, ni el principal salón con su chimenea, elemento que en la época seguía siendo peculiar, mientras que sí se alude a un salón existente en el cuerpo este, y las cocinas del edificio oeste. El nivel de ruina que el propio catastro señala pudo implicar el mal estado de esta ala.

\subsection{Los cuerpos de los lados norte y este}

La muralla norte del castillo terminaba en una amplia torre rectangular maciza en el extremo noreste, situada muy cerca de la pendiente. Y de ella partía un lienzo de

26. La torre del homenaje tenía una más, pero ocupada por el aljibe, al que no se menciona. La sureste solo debía de tener tres plantas. 


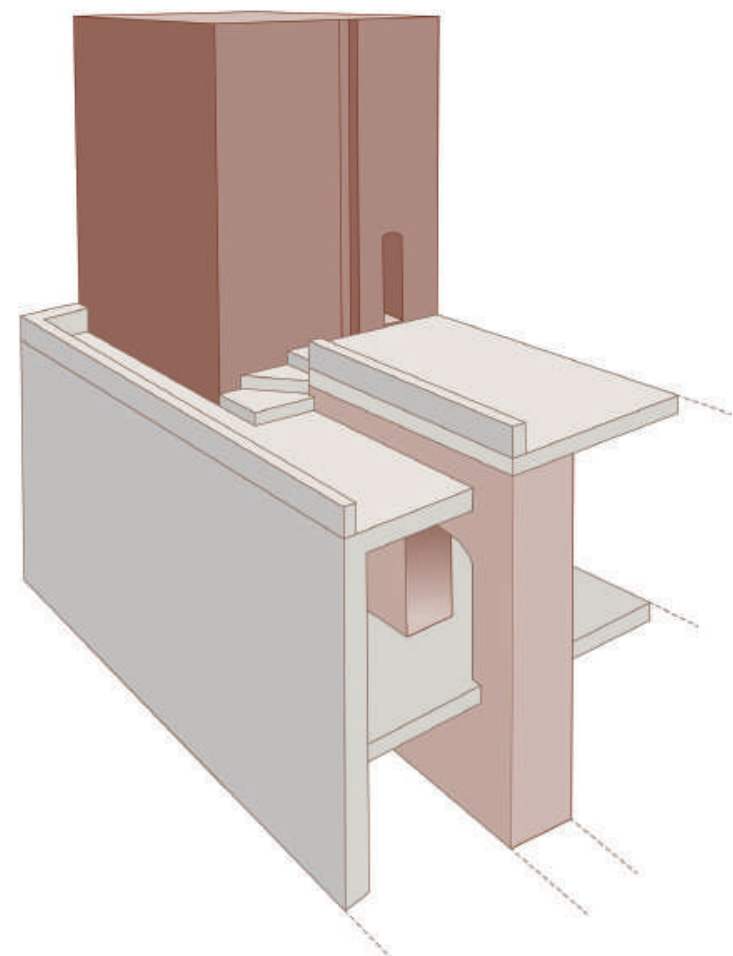

Fig. 23 Diagrama de las dos crujías desde el sur, con los escalones entre las dos plantas

cierre norte-sur, con 15,77 m, que se adaptaba al borde de la pendiente (fig. 5, espacio $H)$, y que trazaba un quiebro, proyectándose hacia el este algo más de $1 \mathrm{~m}$ antes de volver a girar al sur. En la parte más proxima a la torre se encontraba la puerta de entrada al castillo durante la Edad Media, en una posición muy protegida. Al levantar el palacio, se amplió el recinto unos 5,00 $\mathrm{m}$ al este por delante de este tramo de la antigua muralla, construyendo un paramento (fig. 5, espacio K) que arrancó en la ladera unos metros por debajo del plano de aquella, de forma que la primera quedó en el interior, pasando a ser el muro de separación entre dos nuevos edificios, uno paralelo a la muralla norte, sobre el antiguo corredor y otro perpendicular al anterior, sobre la pendiente (fig. 5, espacio J; fig. 24). De la antigua muralla es posible apreciar su trazado, y en la torre la roza de la misma (fig. 25).

Debido a esas nuevas funciones, esta muralla sufrió diversas transformaciones a lo largo del tiempo. La lectura del paramento que queda ha permitido identificar el aparejo original, semejante al de la planta baja de la torre

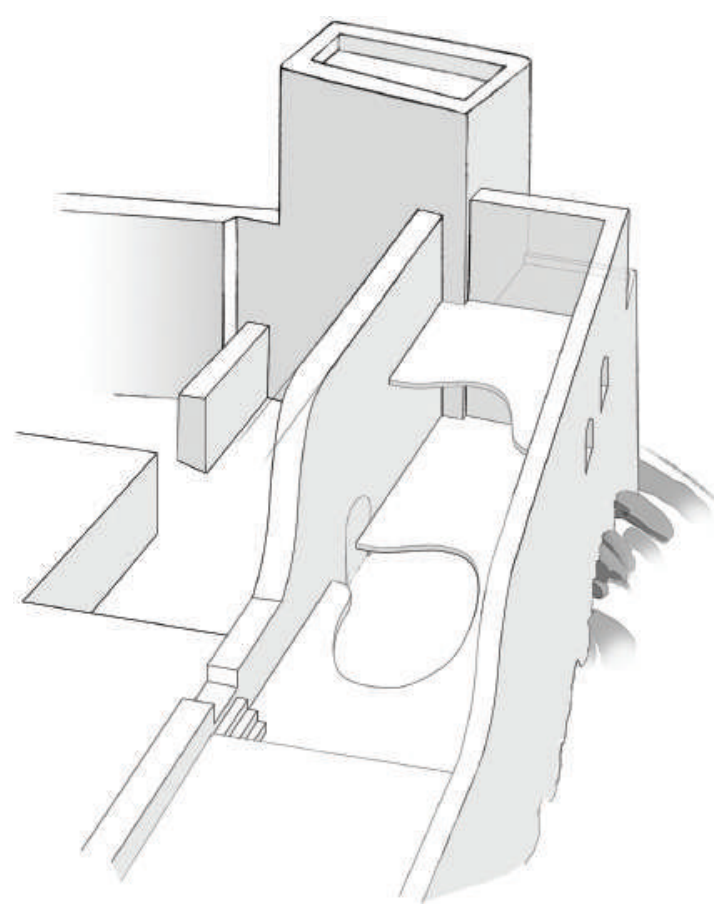

Fig. 24 Esquema del edificio este y el arranque del antiguo camino interior

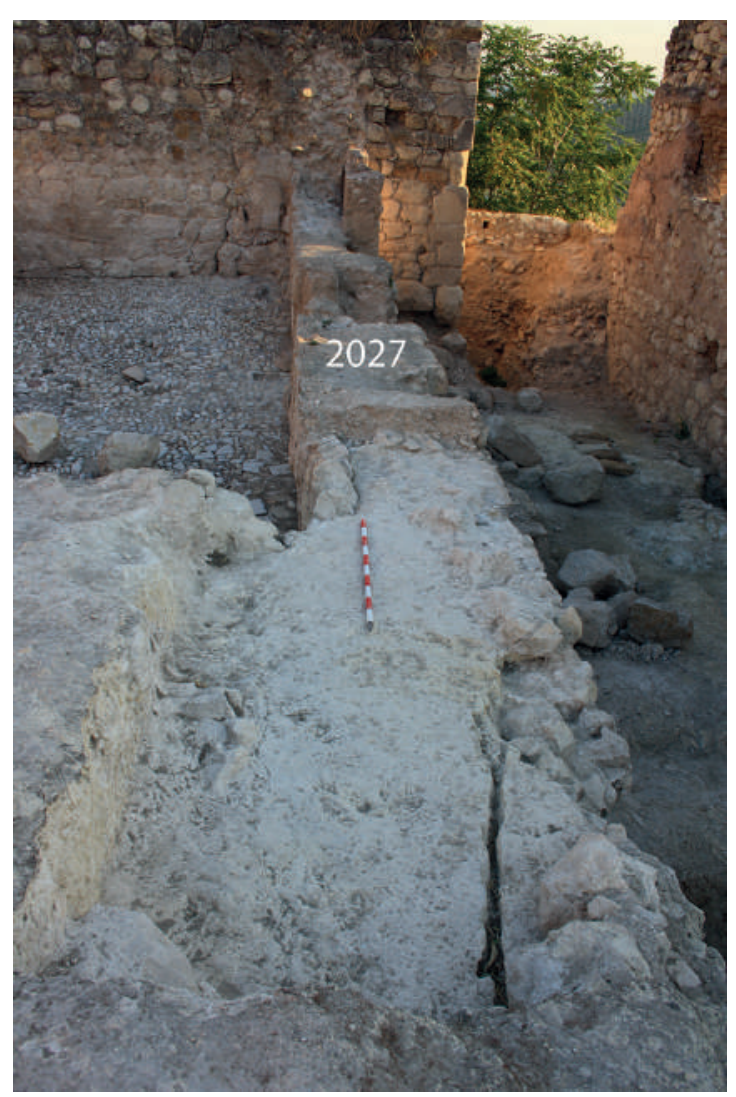

Fig. 25 Antigua muralla de cierre y roza en la muralla norte 
del homenaje (fig. 26, UE 46) y la existencia de diversas aperturas y cierres de vanos, que concluirían en la clausura completa, cuando el recinto del antiguo castillo se convirtió en plaza de toros a principios del siglo XX.

Este conjunto sería con el que el catastro de Ensenada inicia la descripción del edificio, sería el primer cuerpo, que tenía: un salón y dos cuartos, caballeriza seguida de sótano, y cocina en bajo.

El edificio situado al este, sobre la zona que había quedado al exterior del castillo medieval, tenía unos $18 \mathrm{~m}$ de longitud y $4 \mathrm{~m}$ de anchura. Del mismo queda un largo lienzo al este, cuya estructura indica que tenía al menos tres plantas (figs. 27 y 28), se aprecia una en bajo, otra con dos ventanas, visibles tanto al interior como al exterior, y una tercera altura de la que solo quedaban restos del muro exterior, realizado en tapial. La inclinación del terreno generó un espacio que quedó soterrado al interior (fig. 29), donde se introducirían sucesivos sistemas de desagüe, y que estaba cubierto por la planta baja, a la que se accedía desde el norte, junto a la torre maciza, donde se creó una nueva entrada al castillo. Esta planta baja sería el sótano citado en el catastro, al extremo sur del cual se encontraría una cocina, a la que también podía accederse desde el patio del palacio por una escalera, realizada con mortero, que estaba muy deteriorada.

Desde el sótano, a través de un vano, se llegaba a las caballerizas, que constituían la planta baja del segundo edificio, perpendicular al primero, y que se situaron en el antiguo 'camino' de acceso desde la puerta este al patio de armas, entre la muralla norte, y este último. Tenía dos ámbitos. El primero, al que se accedía desde el sótano y el exterior, era un espacio rectangular, con una superficie plana, aunque con una ligera inclinación hacia el centro donde había un sumidero, y tenía un pavimento de guijarros en muy buen estado. La antigua muralla presenta indicios al exterior (fig. 26) de la apertura y cierre de varios vanos a lo largo del tiempo, pero hacia el interior el paramento se recubrió de un grueso enfoscado que los tapó todos menos uno. En este enlucido se abrieron mechinales a baja altura, posiblemente para la instalación de pesebres. El único vano no enfoscado, con una anchura de 1,20 m, debió de ser abierto cuando este lugar se utilizó como caballerizas, ya en el siglo XVI (fig. 30). Fue cegado con mampostería en un momento indeterminado, quizá cuando cambió la función de esta estancia. Se ha abierto ahora para facilitar la comunicación entre los dos espacios.

Desde este se pasaba al segundo ámbito, por un ancho vano, con una ligera rampa, pero gran parte del cierre, sobre todo en el lado sur, ha desaparecido, quedando la impronta de la cimentación. En esa zona existió una letrina.

El segundo espacio (fig. 31) es mucho más amplio, y presenta una ligera pendiente de este a oeste. Desde él se podía acceder a pie al patio de armas por el extremo suroeste. Esta área también estuvo empedrada, aunque el pavimento está más deteriorado. Entre ambos, adosada a la muralla norte, había una escalera, por la que se accedería a la primera planta de ambos edificios. En esta última se encontrarían, encima de las caballerizas, uno de los cuartos mencionados por el catastro, y en el otro edificio el salón, identificable por las dos ventanas al exterior. En la tercera planta de este segundo edificio, estaría el otro cuarto.

En los niveles que rellenaron el sótano del segundo edificio cuando se derribó, se han recuperado algunos materiales decorativos realizados en yeso que pueden fecharse entre el último cuarto del siglo XV y la primera mitad del XVI (fig. 32). Es decir, que pertenecerían a la primera fase de construcción. Pudieron proceder de la sala descrita, aunque tampoco puede descartarse que los mismos provinieran de otro de los edificios, como por ejemplo de la capilla/oratorio ${ }^{27}$.

27. Los materiales de los edificios del palacio, derribados en los siglos XIX y XX, rellenaron estos sótanos, y se distribuyeron por toda la superficie del castillo hasta formar una superficie uniforme. Por tanto, algunos materiales pudieron terminar muy lejos de donde habían estado en un primer momento. 


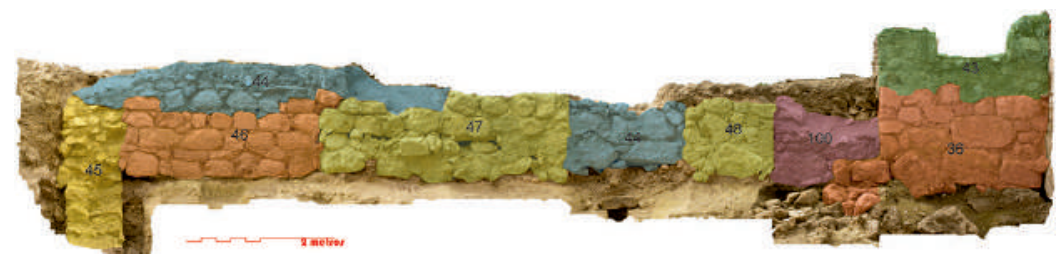

\begin{tabular}{|l|l|l|}
\hline & UUEE. Muro original este & Fase \\
\hline 36 & Torre de mampostería y sillarejo & 3 \\
\hline 43 & Mampostería de pequeño tamaño unida con mortero bastardo & 9 \\
\hline 44 & Mampostería unida con mortero amarillento, Cegado pta. Recrecido muro & 8 \\
\hline 45 & Mampostería unida con mortero de cal. Roza muro norte interior & 2 \\
\hline 46 & Mampostería unida con mortero anaranjado. Muro castillo lado este & 3 \\
\hline 47 & Mamposteria con poco mortero y cal. Reparación cierre fortificación & 4 \\
\hline 48 & Similar a 47. Reparación cierre fortificación formando un vano & 4 \\
\hline 100 & Pequeños mampuestos y abundante mortero. Cegamiento vano original & 6 \\
\hline
\end{tabular}

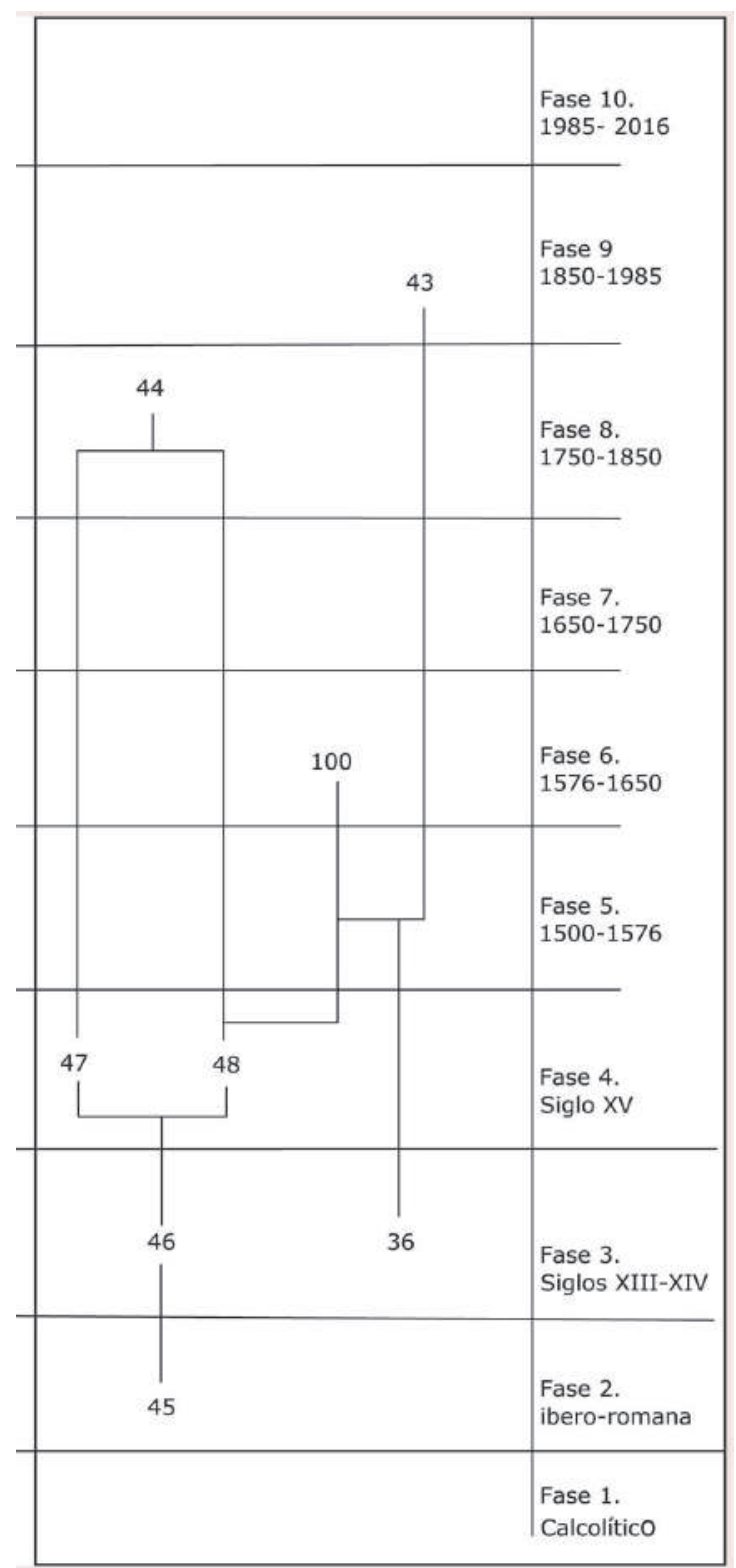

Fig. 26 A) Lectura del lienzo este. B) Relación de UUEE. C) Diagrama estratigráfico 


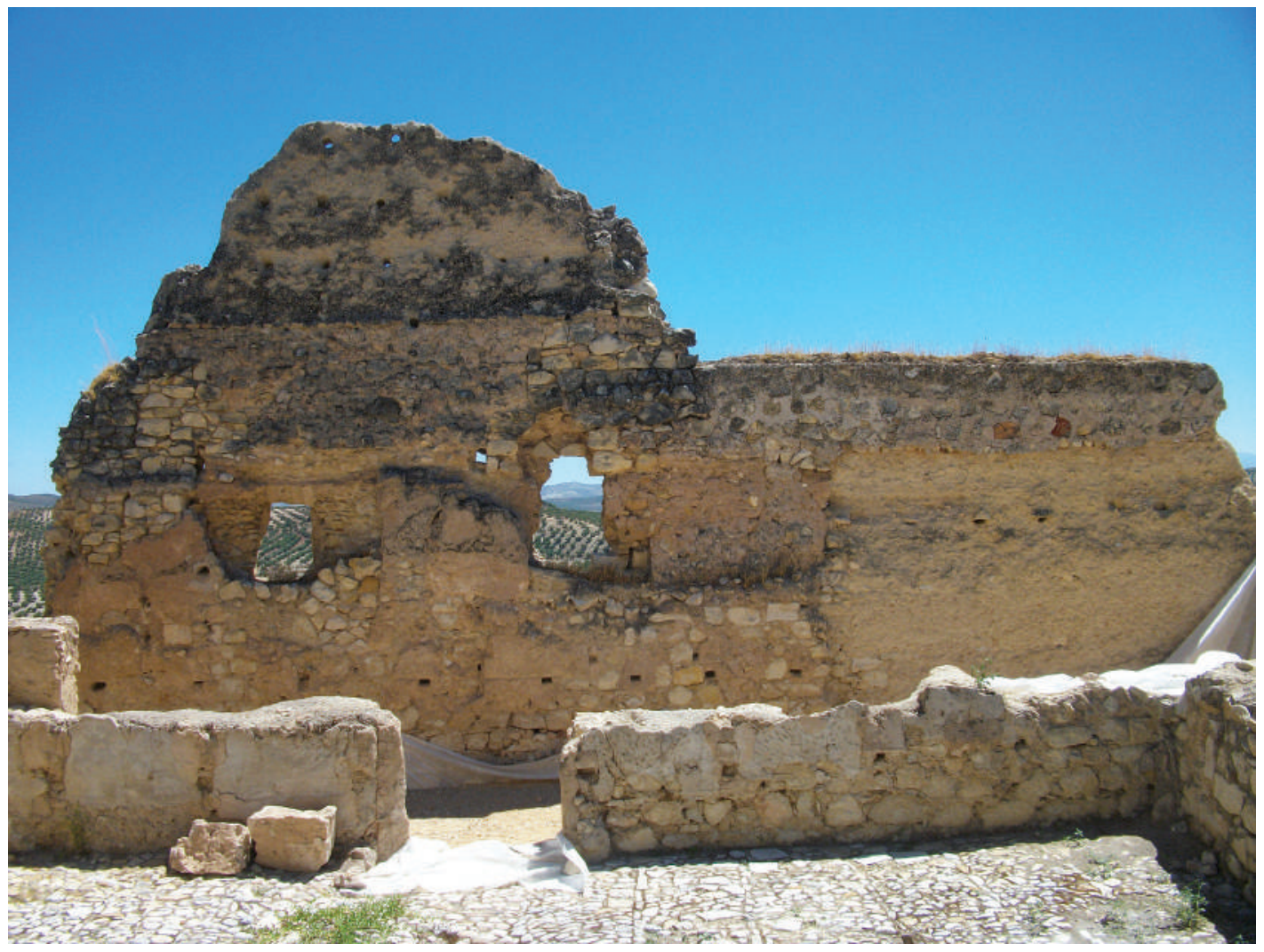

Fig. 27 Lienzo este desde las caballerizas. Se aprecian claramente los tres cuerpos.

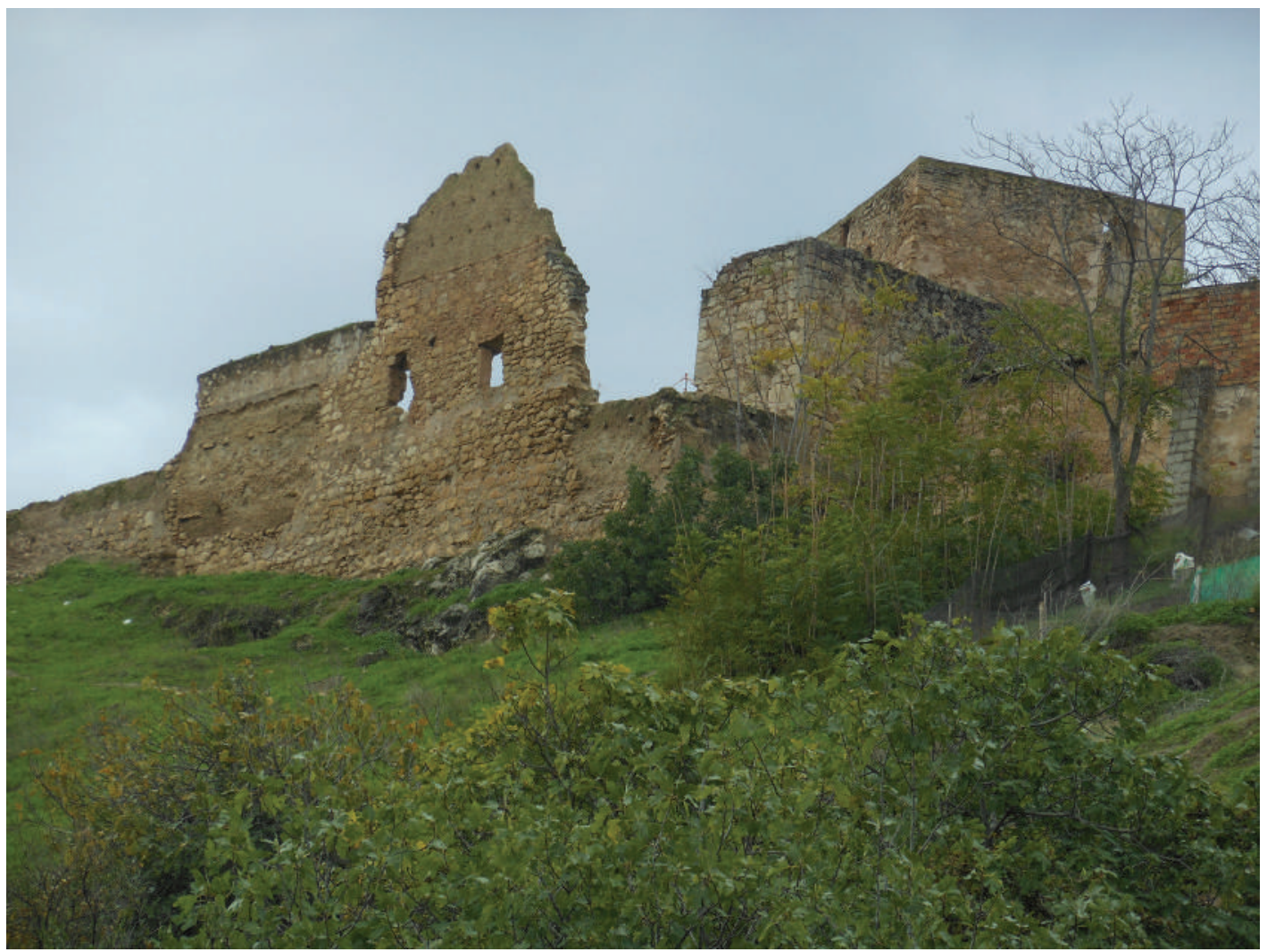

Fig. 28 El lienzo este desde el exterior 


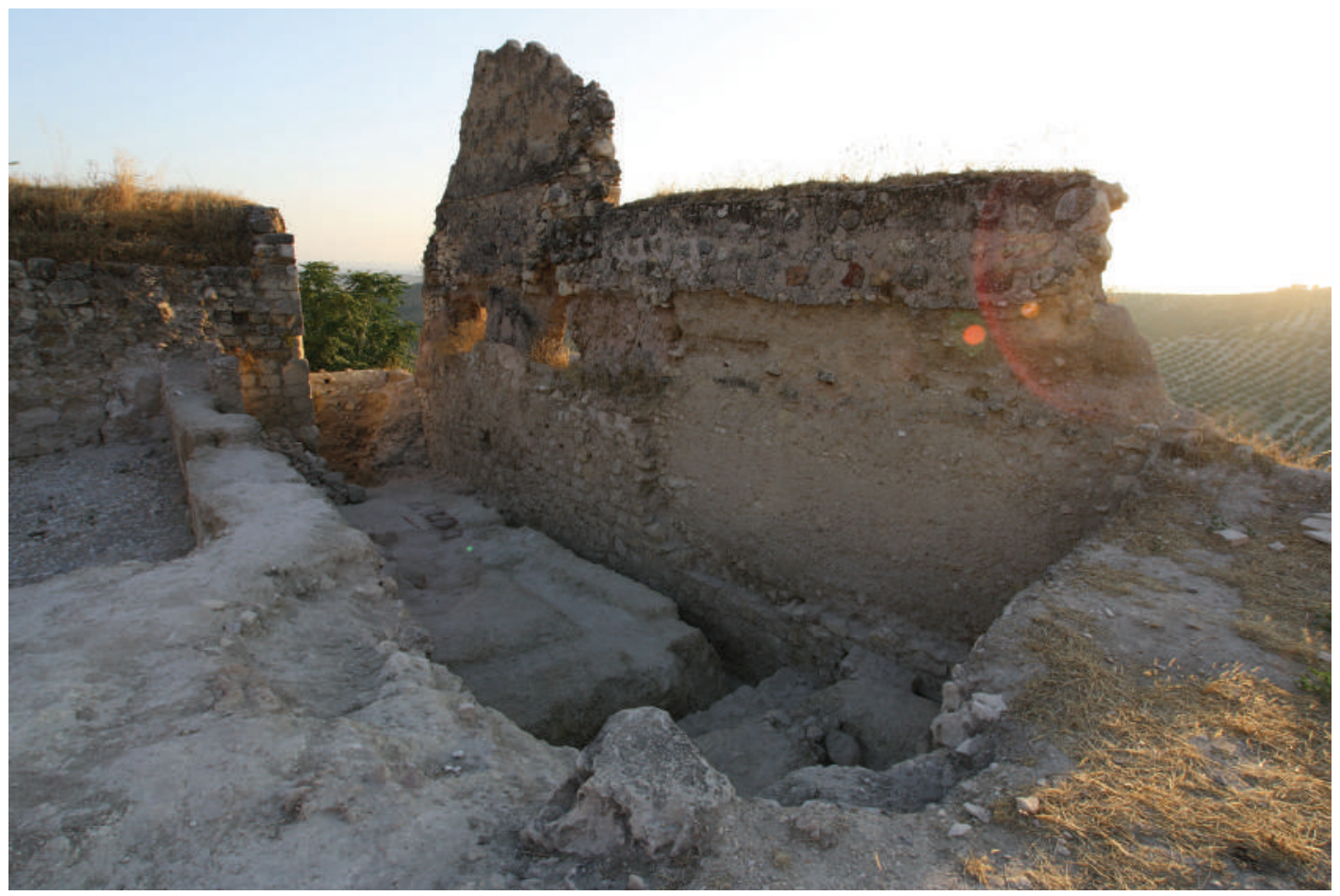

Fig. 29 Espacio soterrado en el edificio este

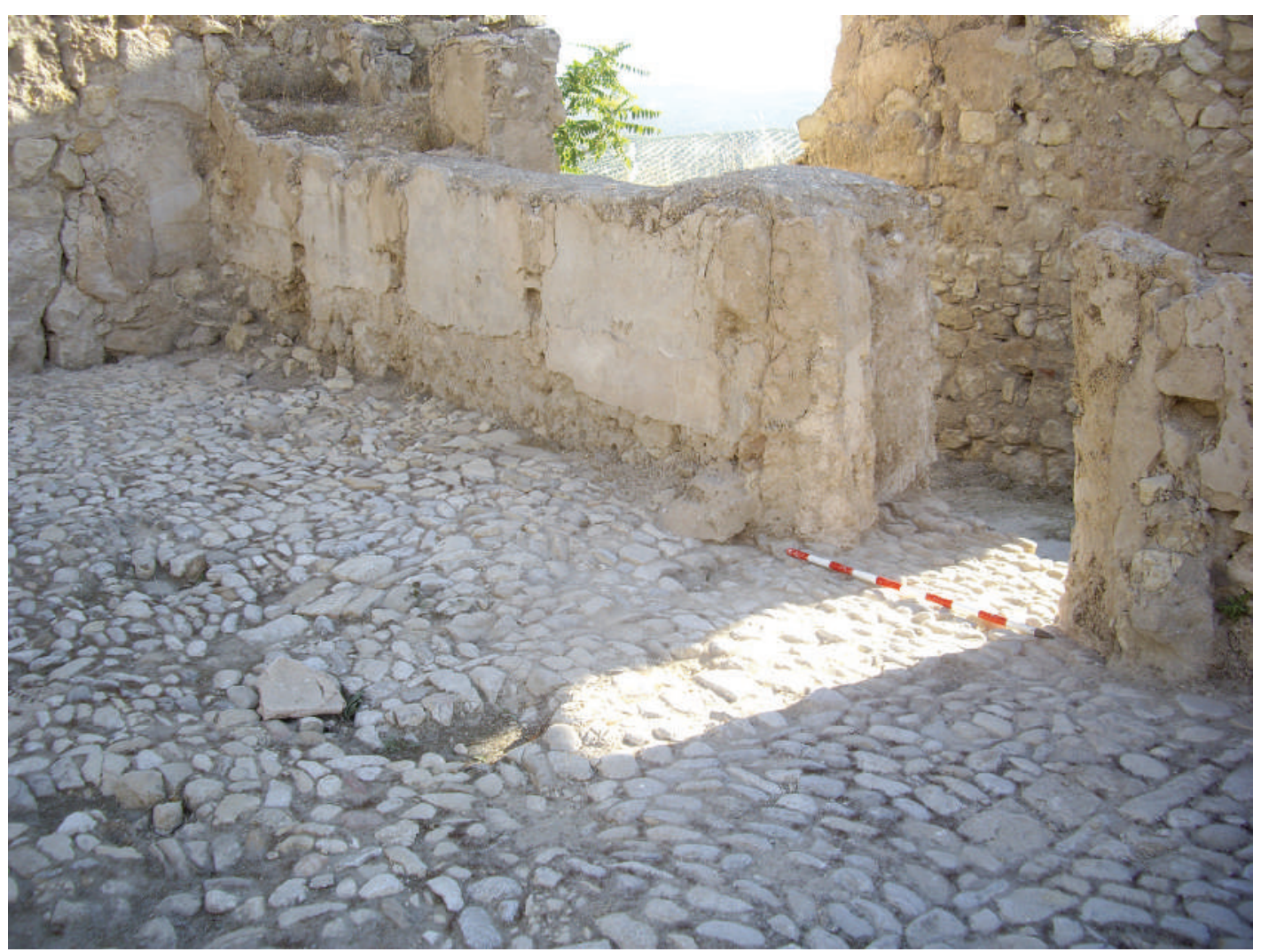

Fig. 30 Acceso a las caballerizas. Se aprecia en el muro de la izquierda un grueso revoco y mechinales, posiblemente para pesebres, dada su altura 


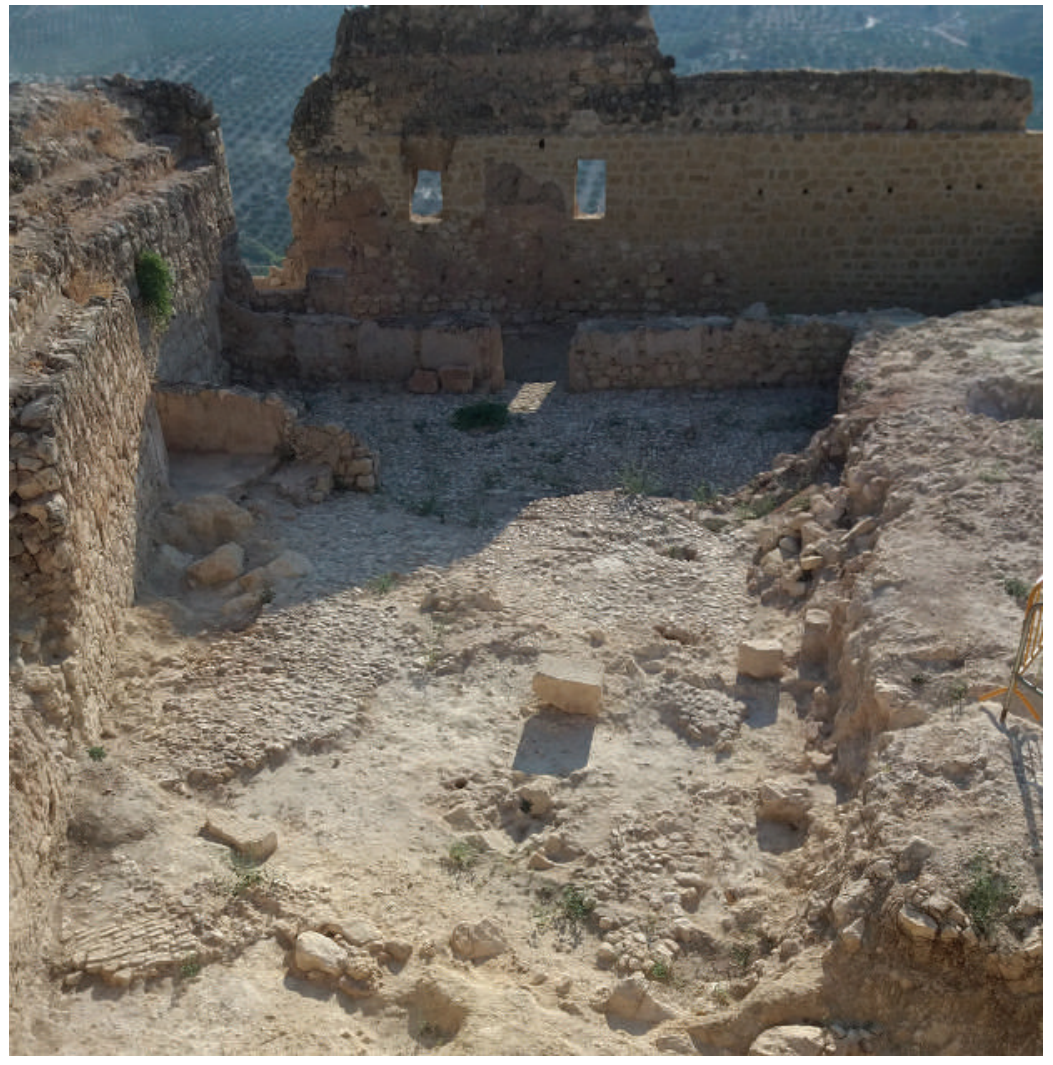

Fig. 31 Vista general de las caballerizas desde el oeste

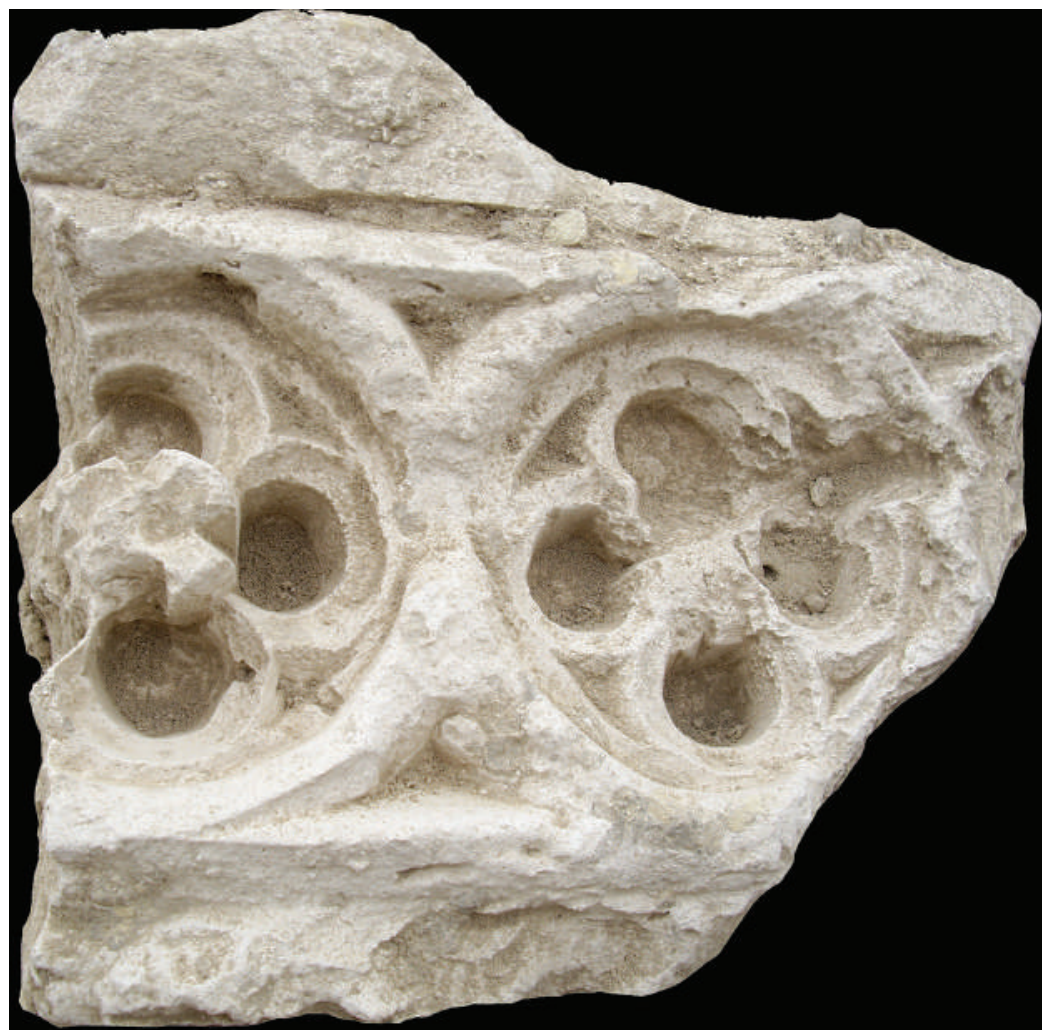

Fig. 32 Restos de decoración realizada en yeso, que presenta una cenefa con dos flores de cuatro lóbulos insertas en sendos círculos 
A unos metros al este del complejo anterior, sobre el borde del cortado, se construyó un pequeño espacio en el interior del cual se instaló una letrina (fig. 5, espacio L; fig. 33), fomada por un espacio de tendencia cuadrada en la parte superior, que comunicaba verticalmente con un canal, que, pasando por debajo de la muralla, llegaba varios metros al exterior (UE 33). No ha sido posible determinar cunado se construyó, pero se la menciona a mediados del siglo XVIII.

A principios del siglo XX se produjo la rgularización de la parcela, y se prolongó el muro exterior (fig. 5, K), hasta enlazar con el extremo sur del polígono. Se hizo levantando un estrecho muro de tapial, que cegó la letrina, que ya no estaba en uso.

\section{LA FUNCIONALIDAD Y EL USO DEL \\ PALACIO}

Una vez realizado el estudio históricoconstructivo del castillo-palacio, creemos que los cuerpos levantados en torno a la antigua torre del homenaje constituirían el 'espacio privilegiado' del palacio, es decir, las habitaciones del conde y la condesa, que como correspondía a la alta nobleza del siglo XVI, tendrían ámbitos separados. Las estructuras situadas al norte y al este estarían dedicadas principalmente al servicio, y quizá a algunos miembros relevantes de la familia.

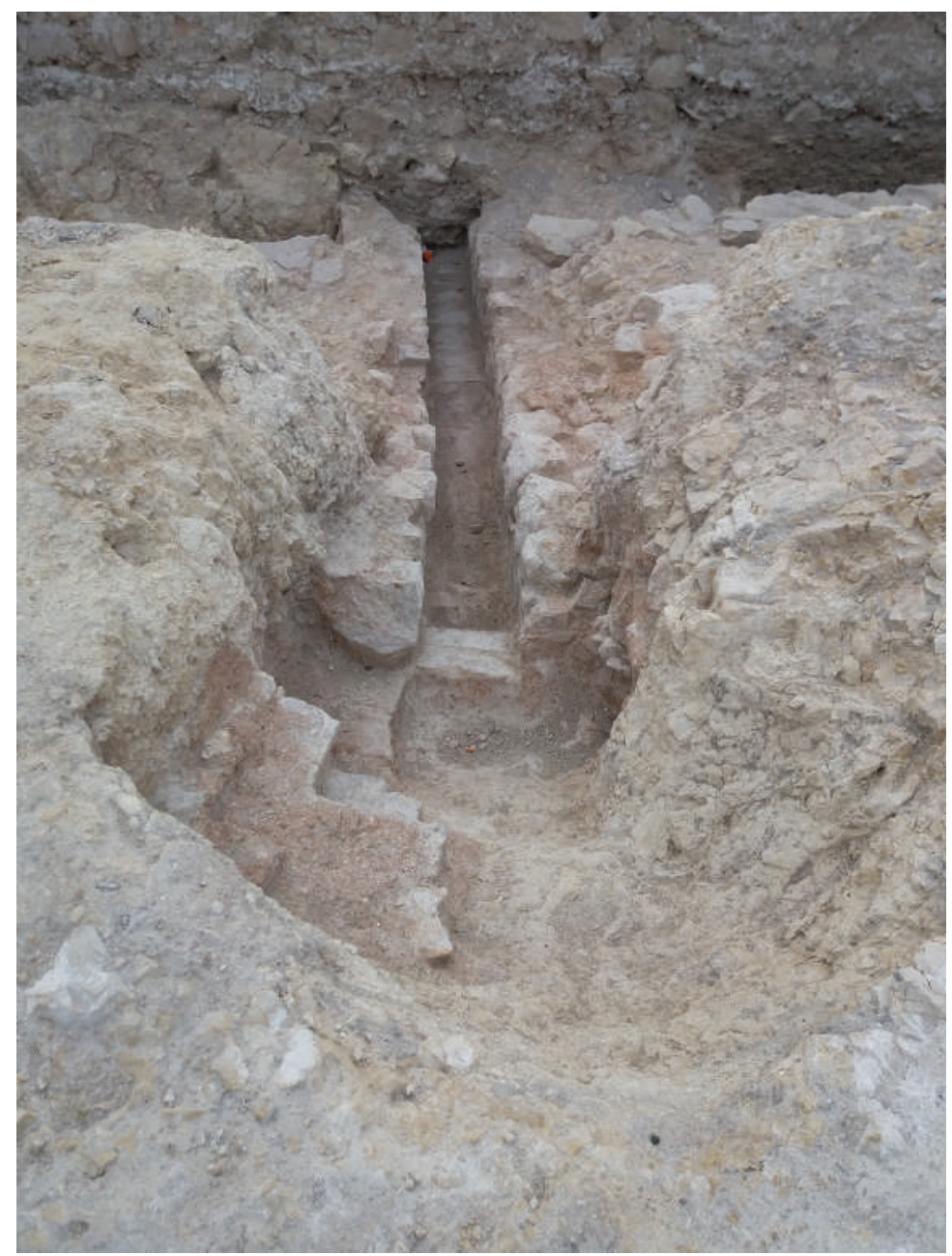

Fig. 33 Restos de la letrina y canal de evacuación, sellado en el siglo XX 


\subsection{El espacio del conde}

El gran salón del edificio sur habría sido el principal espacio representativo del palacio, una nave con un techo bastante alto y dotada de chimenea en el extremo oeste. Dada la falta de indicios, pudo ser un salón con dos naves, pero puesto que el techo de la crujía exterior estaba más bajo, es posible que en realidad esos vanos comunicasen el salón con las habitaciones del conde, que estarían en la nave exterior. Su 'cuarto'28, sus habitaciones privadas, se ordenarían en la característica secuencia de antecámara, cámara y recámara, siendo un indicio de ello un documento que nos informa indirectamente de lo que debía ser, en parte, la fase final de la construcción de este edificio. Se trata de un encargo del 18 de septiembre de 1549 realizado por Juan López de Soria, mayordomo de Fernando de Torres, al rejero de Jaén Agustín de Aguilar, para:

façer tres rejas para su casa del Villardompardo, las dos de un tamaño, que ha de ser cada una dellas dos varas en alto por siete palmos en ancho, e conforme a la rex de la Recamara del quarto nuevo de las dhas casas, e la otra a de ser del tamaño altura e anchura e medida que Francisco de Escalona albañil, dixere e declarase (DOMÍNGUEZ, 1989: 433, doc. LXVI; DOMÍNGUEZ, HENARES, 1989: 244).

El documento parece sugerir que ya se había colocado una reja en la recámara y que en 1549 se encargaron las correspondientes a la antecámara y la cámara, proporcionando su tamaño, 1,67 x 1,46 m, un indicio acerca de las dimensiones de los vanos de cada una de ellas. Esta nave se comunicaba con la planta correspondiente de la torre por la cara sur.

La relevancia de estas habitaciones parece contrastar con la instalación de 'pajeras' en la planta baja, donde la excavación ha localizado grandes huecos para contener tinajas de almacenamiento. No obstante, se trata de un palacio en un ámbito agrícola, en el que esas funciones eran muy relevantes, y desde donde se controlaba la gestión de las rentas del señorío. Y por otro lado, debemos tener en cuenta que la descripción es del siglo XVIII, y hacía más de 150 años que los condes no visitaban el lugar. Es posible que en estos momentos la planta baja estuviera dedicada a labores agrícolas, y de ahí la ubicación en ella de las 'pajeras', como señala el catastro.

Naturalmente, en la época de apogeo, serían necesarias habitaciones para los criados, y para funciones administrativas. Esos espacios pudieron estar en la torre situada en el ángulo sureste, que ha desaparecido, pero cuya planta esquemática aparece dibujada en planos del siglo XIX-XX, y el catastro de Ensenada indica que tenía tres cuartos, suponemos que uno por planta, y quizá el intermedio comunicase con la planta primera. Al oeste de la torre del homenaje, en el otro cuerpo, también de tres plantas y comunicando con ella, pudo haber alguna sala menor, $u$ otros espacios donde el conde podría recibir a sus administradores, a los miembros del cabildo de la localidad para impartir sus instrucciones, a peticionarios de todo tipo, etc. Esos espacios menores estaban situados en realidad al exterior del palacio, teniendo su propio acceso. De esta forma, al ámbito interior solo entrarían los miembros de la 'familia' y las personas de confianza.

\subsection{La escalera principal}

No hay indicios de dónde se encontraba esta, pero la crujía interna estaba cerrada al patio por un muro que, antes de llegar a la antigua torre del homenaje, se interrumpía. De esta forma, entre ese muro y la torre había una amplia zona donde quizá se encontraría la escalera, más o menos monumental que, situada en esta esquina del patio, permitía el acceso desde este último al oratorio y a las primeras plantas de los edificios sur y norte. Lamentablemente, no se conservaban restos de la misma, por lo que solo pueden formularse hipótesis de cómo era.

28. El término podía aludir tanto a una sola estancia, por ejemplo, las distintas plantas de las torres, como a un conjunto de habitaciones con la misma función, como creemos que sucedía en los edificios mayores. 


\subsection{El espacio de las mujeres}

Al describir las reformas que se llevaron a cabo en el castillo de Gibraleón para convertirlo en palacio, A. Aranda señala que era posible "constatar documentalmente una domesticidad femenina absolutamente protocolizada. Nos habla de las ocupaciones de las mujeres en el palacio, de las trabajadoras en los niveles de servicio. Que van a atender fundamentalmente a los niños, las labores de tejido y aguja, la alimentación y la limpieza. Pero también incluye su propio alojamiento e indica que ese será su territorio, segregado del que van a usar el resto de los servidores hombres, cuyas tareas se desarrollarán en esencia fuera del edificio" (ARANDA, 2019: 24).

El de Villardompardo no tiene tamaño para poder establecer dos patios independientes, ni Fernando de Torres y Portugal, en esos momentos, pertenecía a la alta nobleza, ni tendría los grandes medios económicos de esta. Pero, aparte de ello, no hay duda de que la separación de sexos y las funciones deberían de ser similares. Por ello, creemos que el 'cuarto' de la condesa y el conjunto de dependencias femeninas ocuparían el cuerpo adosado a la muralla oeste y a la cara norte de la torre, a través de la que se comunicarían con el edificio sur, y se prolongaría adosado a la muralla oeste.

En la primera planta, con acceso directo al oratorio, estaría la sala, habitación principal de la condesa, junto a su dormitorio. Quizá habría un estrado, espacio eminentemente femenino (CABALLERO, 2017: 423-426). Desconocemos si $F^{a}$ Osorio de Carvajal, primera esposa del primer conde llegó a vivir en el palacio. Pero sí hay datos de que lo hicieron su segunda esposa, $\mathrm{M}^{\mathrm{a}}$
Carrillo de Córdoba, y posiblemente las cónyuges del II conde, al menos M ${ }^{a}$ Polonia Bazán de Mendoza, las cuales debieron de pasar largas temporadas en el mismo, ya que, como se ha indicado, bautizaron en la iglesia de la localidad a la mayoría de sus hijos (tabla 2).

En las otras dos plantas se encontrarían la mayor parte de los cuartos mencionados. Algunos de los espacios femeninos estaban relacionados con el nacimiento y cuidado de los menores, que estaba en manos de las mujeres (DEL VAL, 2008: 66-67, 72-73; CABALLERO, 2017: 411-417). Estos no ocupaban una posición pública relevante, y generalmente eran relegados a las plantas altas. Teniendo en cuenta el elevado número de hijos del primer conde, resulta evidente que se hacía necesario un amplio servicio. Este estaría alojado en las otras dos plantas, probablemente junto a las estancias de los hijos e hijas más pequeños, que desde muy pronto estarían separados por sexos. A partir de la adolescencia, las hijas seguirían confinadas y controladas, frente a la mayor libertad de la que gozarían los varones.

El catastro de Ensenada menciona que en este edificio había tres cocinas. Habría una por planta, y estarían situadas próximas a la torre. Pudieron ser utilizadas según la época, verano/ invierno. O en función de los ocupantes de las plantas de los dos edificios, existiendo la posibilidad de que la comida no fuese la misma para todos, siguiendo la tradición de las leyes suntuarias bajomedievales (GONZÁLEZ 1998: 179188). Durante el Antiguo Régimen, lo normal era que la comida se hiciese individualmente, en los propios aposentos (BLASCO 2017: 89). Tampoco hay que descartar que esta distribución de cocinas sirviera, además, para que en cada planta existiese una estancia caliente, en la que poder

Tabla 2. Los condes y condesas y sus hijos que residieron en Villardompardo

\begin{tabular}{|l|l|c|c|}
\hline \multicolumn{1}{|c|}{ CONDE } & \multicolumn{1}{|c|}{ CONDESA } & HIJOS & HIJAS \\
\hline I Fernando de Torres & Fa Ossorio de Carvajal & 4 & 2 \\
& Ma Carrillo de Córdoba & 4 & 1 \\
\hline Bernardino de Torres & Inés Manrique & 3 & 1 \\
\hline II. Juan de Torres & Isabel de Carvajal & 1 & \\
& Ma Polonia Bazán de Mendoza & & \\
\hline
\end{tabular}


reunirse los ocupantes de cada una de ellas, en función de su estatus.

\subsection{Las caballerizas y los espacios complementarios}

En el edificio situado al norte estaban las caballerizas. El vano de acceso que existió en el último momento, con solo 1,20 m de anchura quizá resulte algo estrecho para el paso de caballos. Es posible que este fuese producto de una reforma de estos espacios en el siglo XVIII, cuando algunos edificios, según el catastro de Ensenada estaban arruinados y quizá, como ya hemos apuntado, parte de las funciones de caballerizas se habían traslado al patio principal y a las naves bajo el edificio sur, lo que explicaría que allí estuviesen las 'pajeras'.

En cualquier caso, encima de las antiguas caballerizas, aparte de almacenes, pudieron alojarse los criados vinculados al cuidado de los caballos. Y quizá otros. Los condes necesitarían responsables del aprovisionamiento, que debía ser abundante en un espacio ocupado por un numeroso grupo de personas. Así como los encargados del mantenimiento y las reparaciones, etc. De estos criados, unos vivirían en el pueblo, pero otros pudieron ocupar estos espacios sobre las cuadras, y quizá algunos de ellos, de especial importancia, el edificio situado al este. No obstante, este último quizá se reservase para visitantes, ya que, aparte del acceso desde las caballerizas, pudo haber otro desde el patio.

\section{VISIBILIDAD Y ENTORNO}

La población de Villardompardo se ubicó en la parte superior de una colina, su centro está constituido por el ayuntamiento y la iglesia que presiden una amplia plaza. La última es el elemento más antiguo que se conserva. Aunque la población se supone fundada en 1245 , las primeras referencias a la iglesia son del siglo siguiente. En 1311 era parroquia del término de Jaén, contando con 1 prebendado y 1/4 (RODRIGUEZ, 1986: 21). Ello parece implicar que existiría un edificio para los oficios religiosos. La iglesia actual data del siglo XVI, aunque la torre en la que se sitúa el campanario parece de finales del siglo XV y en su interior se ubica el antiguo baptisterio, cubierto por una bóveda gótica tardía. Por su posición en el centro de la población, parece casi seguro que está sustituyendo a otra anterior.

Las noticias sobre el castillo son igualmente escasas. Se situó en la parte baja de la colina, al borde del cortado que separa esta del valle del arroyo Salado de los Villares, y que constituyó su mejor defensa. Las excavaciones mostraron que en este lugar había existido un poblado de la edad del cobre y un asentamiento romano de cierta extensión, cuyos materiales se aprovecharían en parte para construir el castillo (MONTILLA, NAVARRO, SALVATIERRA, 2021). Aunque hoy está integrado en la población, hay algunos datos que apuntan a la existencia de una clara separación entre ambos elementos en el pasado. Se han utilizado los métodos de la carta de riesgo urbana (SALVATIERRA, 2013) para estudiar el entorno y tratar de confirmar la existencia de una separación relativamente amplia entre ellos. Con este fin se ha tratado de determinar la localización de la muralla, y se han efectuado mediciones desde el castillo-palacio hasta puntos clave como la iglesia parroquial y el casco histórico, la ermita de Sta. $\mathrm{M}^{\mathrm{a}}$ de Atocha, etc., y que confirman la existencia de una separación inicial entre la población y el castillo de unos 60 o $70 \mathrm{~m}$.

Nos hemos referido anteriormente a la hipótesis de los dos 'partidos' nobiliarios, según la cual los Mendoza y sus aliados llevarían a cabo en sus palacios una reorganización urbanística, que integró ambos elementos, siendo un elemento característico desde el siglo XV la gran portada que se eleva delante de una amplia plaza, a modo de una escenografía. Frente a ellos, los duques de Alba y sus seguidores, mantendrán la separación entre el castillo, muy reformado interiormente, y la población. 
En Villardompardo el foso medieval fue uno de los primeros elementos en ser eliminados en el siglo XVI, rellenándolo. El palacio, más aún que el antiguo castillo, debía de dar la impresión de una mole compacta, debido a los cuatro pisos de su lado oeste. También debían de destacar en la época sus chimeneas, al menos cinco si tenemos en cuenta las cocinas, aunque ignoramos cómo eran. Como remate de estas obras, don Fernando haría instalar una portada renacentista, con su escudo y el de su primera esposa. Delante de esta portada, suprimido el antiguo foso, se crearía una amplia extensión vacía, de más de $60 \mathrm{~m}$ de longitud, hasta las primeras casas de la población, y de unos 70 m sur-norte, desde la ermita de Nuestra Señora de Atocha, hasta su pósito ${ }^{29}$. Una enorme extensión vacía, pero delimitada por edificios que indicaban su presencia, como el pósito y otros elementos constructivos o propiedades de los condes, mencionados en algunos documentos, por lo que, en este ámbito, al igual que en el económico, parece más próximo a la corriente representada por los duques de Alba.

En el siglo XVIII el castillo ya solo distaba de la población 20 varas (unos 17 m), lo que indica que la misma había ido creciendo, sin que los condes actuaran para organizarla. Lo que no implica una completa renuncia a sus privilegios, ya que el plano más antiguo, fechado a finales del siglo XIX, demuestra que aún entonces todo el borde del cortado estaba sin edificar; en estos momentos, o unas décadas antes, la ermita de Sta. $\mathrm{M}^{\mathrm{a}}$ de Atocha quedó progresivamente envuelta por otras casas, y ya no se veía desde el palacio.

En esos momentos el palacio de Villardompardo era solo una más de las posesiones que fueron acumulando los condes, luego marqueses. Las rentas del señorío serían en su mayor parte invertidas en mantener su nivel de vida en la corte, realizando muy pocas inversiones en este lugar, que progresivamente se deterioraría. Se cerrarían las plantas altas de los edificios, mientras que las bajas se dedicaban a funciones agrícolas.

El final de esta etapa coincide con el reinado de Fernando VII, en el primer tercio del siglo XIX, cuando se produce la abolición de los mayorazgos, de forma que la herencia había que repartirla entre los diversos herederos, lo que llevará a la desvinculación del castillo-palacio de Villardompardo de la rama nobiliaria principal, aunque para entonces debía de estar totalmente en ruinas.

\section{CONCLUSIONES}

Durante el siglo XV la ciudad de Jaén, aunque era el principal bastión de realengo frente al reino nazarí, fue la única, de entre las poblaciones de cierta importancia, en la que no se asentaron familias de la alta nobleza ni, de hecho, nobles titulados. Para explicarlo se ha argumentado la dificultad para aprovechar los recursos económicos por el constante estado de guerra (PEREA, 1981: 229). Esa ausencia, por otro lado, explicaría que no se produjera una transformación arquitectónica y urbana.

En la población y su territorio actuaron sobre todo pequeños linajes locales, con recursos limitados. En el siglo XV, como ya hemos señalado, la ciudad va a estar dominada por los Torres y por una rama menor de los Mendoza. Las acciones de los primeros, que son los que nos han interesado aquí, nos los presentan como defensores de la economía rentista medieval, siendo los derechos sobre la almocatracía, los del estanco relacionado con los tintes y otros, la base de gran parte de sus ingresos (MOLINA, 1983: 44). Su principal posesión, el señorío de Villardompardo, a unos 20 km de Jaén en línea recta, incluía algunas aldeas, pero nunca tuvieron los medios de los nobles de Córdoba o Sevilla o de otras zonas peninsulares. En la segunda mitad del siglo $X V I$, D. Fernando de Torres pasó de estar marginado por Carlos V, por la implicación de su

29. En el lateral norte de la actual plaza del Castillo hay un edificio, que quizá esta adosado a la muralla por el interior, en el que subsisten arcadas y empedrados. En base a algunas referencias se ha identificado con el pósito del conde. 
padre en la revolución de las Comunidades de Castilla, a ser nombrado conde, y luego virrey del Perú, por Felipe II. Ese proceso solo pudo producirse, además de por una buena capacidad diplomática para 'hacer las paces' con el monarca, quizá a través de las devociones religiosas, por su compromiso con alguna de las redes clientelares nobiliarias que le dieran su apoyo. En parte, ese compromiso puede leerse a través del palacio que construyó, y de la relación del mismo con la población, donde se observan evidentes coincidencias con el 'modelo' de villa medieval y castillo, que representaron, a mucha mayor escala, los duques de Alba y los linajes relacionados con ellos.

Se ha puesto de manifiesto, en numerosas ocasiones, la notable dificultad para reconstruir cómo eran originalmente los palacios de la nobleza, por haber desaparecido, estar en ruinas, o embutidos y trasformados en el interior de edificaciones modernas (CABALLERO, 2017: 399). El palacio de los condes de Villardompardo, en esta población, había desaparecido a finales del siglo XIX. Los muros que permanecen aún en pie, en un examen superficial, apenas revelan nada de cómo fue. Y la descripción del catastro de Ensenada resulta confusa. Pero al conectar esa descripción con los resultados de las excavaciones y sobre todo el estudio realizado desde la arqueología de la arquitectura, se ha conseguido una imagen cuyos contornos empiezan a adquirir nitidez. Y a partir de la comparación con otros edificios, según los análisis efectuados en las últimas décadas, ha sido posible comprender cómo había sido realmente el palacio, su entidad y sus funciones.

Lamentablemente, aunque podamos deducir dónde estaban respectivamente los ámbitos masculinos y femeninos, y por tanto tratar de interpretar la distribución y organización general del espacio, nada sabemos de cómo eran los mismos, ni de cómo se vivía en este lugar, ya que han desaparecido por completo. En este sentido poco se puede añadir a lo también poco que se conoce sobre ellos (MARÍAS 1994: 167-180). La identificación de cómo eran esos ambientes se ha realizado, en otros lugares, empleando imágenes y relatos, en ocasiones por el mantenimiento de elementos decorativos concretos (LÓPEZ TORRIJOS, 2017: 125-152), y con frecuencia recurriendo a generalizaciones más o menos precisas (CABALLERO, 2017: 397-428). Esos son los elementos que hemos intentado aplicar a este conjunto.

\section{BIBLIOGRAFÍA}

ALCÁZAR HERNÁNDEZ, Eva Ma (2008): Aldeas y cortijos medievales de Jaén. Jaén: Instituto de Estudios Giennenses.

ALEGRE CARVAJAL, Esther (1999): Las villas ducales como tipología urbana. El ejemplo de la villa ducal de Pastrana. Tesis Doctoral. UNED.

ALEGRE CARVAJAL, Esther (2008): "La configuración de la ciudad nobiliaria en el Renacimiento como proyecto ideológico de una elite de poder", Tiempos Modernos Revista electrónica de Historia Moderna, 16, 1-19.

ALONSO RUIZ, Begoña (2014): "La catedral gótica de Jaén”, Laboratorio de Arte, 26, 47-71. https://doi.org/10.18002/da.v0i11.1003

ARANDA BERNAL, Ana Ma (2019): "Un hogar para los marqueses. La transformación de la fortaleza medieval de Gibraleón en un palacio del quinientos", en Ma E. Díez (ed.), De puertas para adentro. La casa en los siglos XV-XVI, 3-37. Granada: Comares, 3-37.

ARCO MOYA, Juan del (2007): "Documentos del conde del Villar en el Instituto de Estudios Jienenses", Elucidario 3, 407-409.

ARGOTE DE MOLINA, Gonzalo (1991): Nobleza de Andalucía. Jaén: Riquelme y Vargas Ediciones (ed. facsímil de la de 1866-1879. $1^{\text {a }}$ ed. Sevilla, 1588).

AZKARATE GARAI-OLAUN, Agustín; CABALLERO ZOREDA, Luís; QUIROS CASTILLO, Juan Antonio (2002): "Arqueología de la Arquitectura: Definición disciplinar y nuevas perspectivas", Arqueología de la Arquitectura, 1, 7-10

BLASCO ESQUIVIAS, Beatriz (2006): "Los espacios de la necesidad: alimentación, higiene y descanso nocturno", en B. Blasco (dir), La casa. Evolución del espacio doméstico en España. vol 1. Edad Moderna, 17-124. Madrid: Ediciones El Viso.

BLASCO ESQUIVIAS, Beatriz (2017): "Vivir y convivir. Familia y espacio doméstico en la Edad Moderna”, en M. Birriel (ed.), La(s) casa(s) en la Edad Moderna, 62-92. Zaragoza: Institución Fernando El Católico.

BONET CORREA, Antonio (2018): "Las chimeneas de El Escorial", $P+C$ : proyecto y ciudad: revista de temas de arquitectura, 9, 5-16.

CABALLERO ESCAMILLA, Sonia (2017): "Lugares donde disfrutar, morar y rezar. La diversidad del ámbito doméstico en el tardogótico hispano", en M ${ }^{a}$ E. Díez (ed.), De puertas para adentro. La casa en los siglos XV-XVI, 397-428. Granada: Comares.

CÁMARA, Leandro; LATORRE, Pablo (2003): "El modelo analítico tridimensional obtenido por fotogrametría. Descomposición, 
manipulación y aplicaciones en el campo de la restauración arquitectónica", Arqueología de la Arquitectura 3, 87-96. https://doi. org/10.3989/arq.arqt.2003.29

CASEY, James (1991): Historia de la familia. Madrid: Espasa Calpe

CASTILLO ARMENTEROS, Juan Carlos, CASTILLO ARMENTEROS, José Luis (2001): "Aportaciones arqueológicas al estudio de las fortificaciones señoriales del Alto Guadalquivir (Jaén) entre los siglos XV y XVI", en I.C. Ferreira (ed.) Mil ano de Fortificaçoes na Peninsula Ibérica e no Magreb (500-1500): Actas do Simposio Internaciona sobre Castelos, 719-732. Lisboa, Ediçoes Colibri/ Câmara Municipal de Palmela.

CUEVAS MATA, Juan; ARCO MOYA, Juan; ARCO MOYA, José (2001): Relación de los hechos del mui magnifico e mas virtuoso señor, el señor don Miguel Lucas, muy digno condestable de Castilla. Jaén: Universidad de Jaén.

DEL VAL VALDIVIESO, Ma Isabel (2008): "Los espacios del trabajo femenino en la Castilla del siglo XV", Studia histórica. Historia Medieval, 26, 63-90.

DOMíNGUEZ CUBERO, José (1989): La rejería de Jaén en el siglo XVI. Tesis Doctoral. DIGIBUG, Universidad de Granada,433 Doc. LXVI (1028)

DOMÍNGUEZ CUBERO, José (1991): "Contrato de la reja de la capilla del virrey del Perú, en la desaparecida catedral de Jaén", Boletín del Instituto de estudios Giennenses, 143,7-38, Jaén.

DOMÍNGUEZ CUBERO, José; HENARES CUELLAR, Ignacio L. (1989): La rejería en Jaén en el siglo XVI. Jaén: Instituto de Cultura, Diputación Provincial.

ENSENADA, Marqués de la (1751): Catastro. Libro mayor de legos. A.H.N

ESLAVA GALÁN, Juan (1999): Los castillos de Jaén. Granada: Osuna.

GARCÍA GONZÁLEZ, Francisco (2017): "Casas, itinerarios, trayectorias. Espacializar la historia social en el Antiguo Régimen”, en M. Birriel (ed.), La(s) casa(s) en la Edad Moderna, 45-63. Zaragoza: Institución Fernando El Católico.

GONZÁLEZ ARCE, José Damián (1998): Apariencia y poder. La legislación suntuaria castellana en los siglos XIII-XV. Jaén: Universidad de Jaén.

HARRIS, Edward C. (1991). Principios de estratigrafía arqueológica, Barcelona: Crítica (1 $1^{\mathrm{a}}$ ed en inglés 1979).

LÁZARO DAMAS, Soledad (2003): "Aportaciones documentales para el estudio biográfico del arquitecto renacentista Alonso Barba", Boletín del Instituto de Estudio Giennenses, 184, 9-28.

LÓPEZ TORRIJOS, Rosa (2017): "La vida en un palacio. Imágenes y datos sobre espacios masculinos y femeninos en el siglo XVI", en M. Birriel (ed.), La(s) casa(s) en la Edad Moderna, 125-133, Zaragoza: Institución Fernando El Católico.

MARÍAS FRANCO, Fernando (1994): "Arquitectura y vida cotidiana en los palacios nobiliarios españoles del siglo XVI", en J, Guillaime (ed.): Architecture et vie sociale 'a la Renaissance. L'organisation intérieure des grandes demeures à la fin du Moyen Age et à la Renaissance. Actes du colloque tenu à Tours du 6 au 10 juin 1988, 167-180. París: Picard.
MEMORIAL DEL PLEITO (1657): Memorial de pleito que trata la Compañia de Jesús de la ciudad de Jaén... con D. Juan de Torres y Portugal". Granada: Archivo de la Real Chancillería de Granada.

MILETO, Camilla; VEGAS, Fernando (2003): "El análisis estratigráfico constructivo como estudio previo al proyecto de la restauración arquitectónica: metodología y aplicación", Arqueología de la Arquitectura, 3, 189-196. https://doi.org/10.3989/arq.arqt.2003.46

MOLINA MARTínEZ, Miguel (1983): "Los Torres y Portugal del señorío de Jaén al virreinato peruano", en B. Torres y J. Hernández (coords.), Andalucía y América en el siglo XVI. Actas de las II Jornadas de Andalucía y América, vol. II, 36-66. Madrid: CSIC.

MONTILLA TORRES, Irene; NAVARRO PÉREZ, Mercedes (2011): "La arqueología de la arquitectura”, en V. Salvatierra Cuenca, y M. Navarro Pérez, M. (eds.), El palacio Villalvos Nicuesa (Jaén). Un estudio desde la arqueología de la arquitectura, pp 67-140, Jaén.

MONTILLA TORRES, Irene; NAVARRO PÉREZ, Mercedes (2014): El Renacimiento Giennense desde la arqueología de la arquitectura. Instituto de Estudios Giennenses. Inédito.

MONTILLA TORRES, Irene; NAVARRO PÉREZ, Mercedes; SALVATIERRA CUENCA, Vicente (2021): "Villardompardo (Jaén). Del asentamiento romano al castillo medieval", Lucentum XL, 1-22. https:// doi.org/10.14198/LVCENTVM.18686

MORA-FIGUEROA, Luis de (2006): Glosario de arquitectura defensiva medieval. Madrid: Ministerio de Defensa.

NICÁS MORENO, Andrés (1997): Heráldica y genealogía en el reino de Jaén. Jaén: Instituto de Estudios Jienenses.

PEREA CARPIO, Carmen (1981): "Intervención de linajes giennenses en los problemas sucesorios de la segunda mitad del siglo XV", Cuadernos de Estudios Medievales y Ciencias y Técnicas Historiográficas, 6-7, 229.235. Granada.

PÉREZ GARCíA, Rafael M. (2011): "Espirituales, cortes señoriales y linajes nobiliarios. Construcción y desarrollo de climas sacro-espirituales de referencia social en la Andalucía de los siglos XVI y XVII", Historia y Genealogía 1, 135-153. https://doi.org/10.21071/ hyg.v0i1.319

PORRAS ARBOLEDAS, Pedro A. (1989): "Aportación al estudio del Mayorazgo. Tres ejemplos giennenses en los siglos XIV-XV-XVI", Boletín del Instituto de Estudios Giennenses, 139, 63-100.

PORRAS ARBOLEDAS, Pedro A. (1990): "La aristocracia urbana de Jaén bajo los Trastámara: Los Mendoza y Los Berrio", En la España Medieval, 13, 271-301.

PORRAS ARBOLEDAS, Pedro A. (1993): La ciudad de Jaén y la revolución de las Comunidades de Castilla (1500-1523). Jaén: Instituto de Estudios Giennenses.

RAMOS VÁZQUEZ, Isabel (2002): El Concejo de Jaén (1474-1556). Jaén: Universidad de Jaén.

RODRÍGUEZ MOLINA, José (1986): El obispado de Baeza-Jaén. Organización económica y diocesanas (Siglos XIII-XVI). Jaén: Instituto de Cultura. Diputación provincial de Jaén.

ROMERO DE TORRES, Enrique (1915): Catálogo de los Monumentos Históricos y Artísticos de la provincia de Jaén, vol III, 234-236, fotos vol. 9, 550-551. 
SALVATIERRA CUENCA, Vicente (2013): "En los adentros de la ciudad. Arqueología y urbanismo", en J.A. Quirós, La materialidad de la historia. La arqueología en los inicios del siglo XXI, 241-270, Akal.
SCHRADER, Jeffrey (2006): La virgen de Atocha. Los Austrias y las imágenes milagrosas. Madrid: Ayuntamiento de Madrid. 